\title{
Context in international business: Entrepreneurial internationalization from a distant small open economy
}

\author{
Eldrede T. Kahiya \\ School of Marketing and International Business, Victoria University of Wellington, 23 Lambton Quay, Pipitea, Wellington, New Zealand
}

\section{A R T I C L E I N F O}

\section{Keywords:}

Systematic review

Entrepreneurial internationalization

Incremental models

Born globals

International new ventures

Exporting

SMEs

\begin{abstract}
A B S T R A C T
Context matters in International Business, but to what extent does it influence the content of knowledge? This study offers a systematic literature review on the internationalization of New Zealand firms. A geographically isolated small open economy (SMOPEC) with audacious trade aspirations, a strong domestic institutional environment, favorable attitude toward trade, and entrepreneurial small-to-medium size enterprises (SMEs), New Zealand provides an enlightening context to study internationalization. Using a sample of 95 studies, the review identifies antecedents, stimuli, capabilities, strategy, process and outcomes underpinning internationalizing New Zealand firms (INZFs). Context matters but not in the manner anticipated. On one hand research on the internationalization of New Zealand firms is largely congruent with extant knowledge, on the other the New Zealand context shapes uniquely, how and what scholars choose to research.
\end{abstract}

\section{Introduction}

The purpose of this study is to explore if and how context shapes the internationalization of firms from the small open economy (SMOPEC) of New Zealand. Interest in understanding the SMOPEC context originates from economics where researchers (e.g., Correia, Neves, \& Rebelo, 1995; Mendoza, 1991) studied business cycles and myriad economic indicators. But how does the SMOPEC context shape internationalization? The study responds to sustained calls (e.g., Michailova, 2011; Poulis, Poulis, \& Plakoyiannaki, 2013; Schotter, Buchel, \& Vashchilko, 2018; Teagarden, Von Glinow, \& Mellahi, 2018; Tsui, 2007; Welch, Piekkari, Plakoyiannaki, \& Paavilainen-Mäntymäki, 2011) for greater contextualization in International Business (IB). Context maps boundary conditions within which theory is generalizable, engenders nuance, and provides a basis for verification or falsification of theory (Poulis et al., 2013; Teagarden et al., 2018). That IB research suffers from inadequate contextualization is unwarranted given context lies at the very core of the field (Michailova, 2011; Teagarden et al., 2018).

To shed light on how context may influence knowledge, the study employs a systematic literature review on the internationalization of New Zealand firms. Several scholars (e.g., Jones, Coviello, \& Tang, 2011; Knight \& Liesch, 2016; Ribau, Moreira, \& Raposo, 2018) continue to call for the incorporation of context as a means to foster theoretical advancements in internationalization research. Jones et al. (2011, p. 648 ) in particular, contend the "continuance of debate and theorizing is healthy and appropriate". Depicting the internationalization of New
Zealand firms as a unique context-embedded subject, the study collates and synthesizes knowledge with the goal of contributing to theory. Antecedents, stimuli, capabilities, strategy, process, and outcomes encapsulate the dynamics of internationalizing New Zealand firms (INZFs). A synthesis of the linkages between the factors and nuanced interpretation of context enrich the discourse on entrepreneurial internationalization.

Uniqueness of context justifies restricting the scope of a literature review to a specific country (see Caputo, Pellegrini, Dabic, \& Dana, 2016; Da Rocha \& Christensen, 1994; Deng, 2012; Endo, Delbridge, \& Morris, 2015; Ibeh, Wilson, \& Chizema, 2012; Wheeler, Ibeh, \& Dimitratos, 2008). Wheeler et al. (2008) cite the UK's lackluster export performance as the motivation for appraising literature on the performance of internationalizing UK firms (IUKFs). Deng's (2012) review on internationalizing Chinese firms (ICFs) stems from the rising stature of China as an economic power and the need to better understand emerging market multinational enterprises (EMNEs). An earlier review by Da Rocha and Christensen (1994), on the export behavior of Brazilian firms, adopted similar reasoning. In a systematic literature review on internationalizing Central and Eastern European firms (ICEEFs), Caputo et al. (2016) justify their research on (1) the imperative to develop taxonomy on transitioning and developing countries and (2) the historical significance of the region, which, in the authors' view, was part of the Old Silk Road. Likewise, Endo et al's. (2015) critique on the international operations of Japanese MNEs highlights as raison d'être, the historical prominence of Japanese enterprises in informing Operations

E-mail address: eldrede.kahiya@vuw.ac.nz. 
Management and (OM) International Business (IB). The dearth of research on internationalizing African firms (IAFs) is Ibeh et al.'s (2012) justification for confining a review to this region. This study adds New Zealand to the small but growing list of reviews linking context to content of knowledge.

As an export-driven small open economy (SMOPEC), New Zealand shares similarities with contemporaries (e.g., Denmark, Norway, Portugal, Spain, and Sweden) in the Organization for Economic Cooperation and Development (OECD). Ventures that internationalize from a SMOPEC base strive to become global players while facing fierce global competition (Hielkema \& Hongisto, 2013). Further, New Zealand (and Australia) may be the only OECD members that do not have close access to a large neighboring trade partner or consumer market. This geographic isolation makes New Zealand a distant small open economy (D-SMOPEC) and presents an additional challenge - targeting distant markets. It is no happenstance that the McKinsey report (see Rennie, 1993), which is recognized as the seminal paper on born global firms examined an Australian sample - firms that operate in a context analogous to New Zealand's.

New Zealand's merchandise exports are agriculture-based, with dairy and meat accounting for the bulk. The country's comparative advantage in these sectors goes back 150 years although it has only blossomed over the past five decades (New Zealand Institute of Economics Research, 2009). While this reliance on agriculture is akin to the commodity-based economies of Sub-Saharan Africa, New Zealand differs fundamentally from these countries, principally, concerning the level of economic development, quality of the institutional environment, and attitudes toward free trade ${ }^{1}$. In spite of this, recent years have seen New Zealand's export performance flounder, with the country dropping into the bottom half of OECD rankings ${ }^{2}$. This makes New Zealand somewhat of an anomaly in that the economic freedoms, positive predisposition toward free trade, and high total early stage entrepreneurial activities (see Marcotte, 2013) have not attracted a commensurate level of economic growth (Frederick \& Monsen, 2011).

This study focuses on country (home-market) context and the "topography of the institutional" setting (Jackson \& Deeg, 2008) outlined above suggests that from a theoretical perspective, New Zealand may be to the internationalization discourse, what a unique case is to qualitative case study research (Eisenhardt \& Graebner, 2007; Flyvbjerg, 2006; Siggelkow, 2007; Stake, 1995). Unique cases, be they critical, deviant/ extreme, or paradigmatic are predicated on some degree of variation (Fletcher, Zhao, Plakoyiannaki, \& Buck, 2018; Flyvbjerg, 2006; Stake, 1995). The study casts the internationalization of New Zealand firms as a critical case (i.e., one which enables the falsification or verification of theory) (Baxter \& Jack, 2008; Flyvbjerg, 2006). Verification employs the logical deduction of "if this (i.e., content of mainstream research) is valid for this case, then it applies to all" (Flyvbjerg, 2006, p. 230). Past research on context in IB (e.g., Michailova, 2011; Poulis et al., 2013; Teagarden et al., 2018), which indicates contextual differences will likely lead to the falsification of theory, guides this study. Taking a cue from (Flyvbjerg, 2006, p. 232), the study proposes;

The internationalization of New Zealand firms is 'most likely' to differ from (or 'least likely' to be congruent with) mainstream research given the uniqueness of context.

To examine this proposition the study answers the following questions;

\footnotetext{
${ }^{1}$ For instance, New Zealand joined the General Agreement on Tariffs and Trade (GATT), and the World Trade Organization (WTO), at inception, became the first Western country to sign a Free Trade Agreement with China, ratified the Government Procurement Agreement (GPA) in 2015, and is attempting to resuscitate negotiations on the Trans-Pacific Partnership Agreement (TPPA).

${ }^{2}$ See OECD (2018), Trade in goods and services (indicator). doi: https://doi. org/10.1787/0fe445d9-en (Accessed on 13 February 2018).
}

1) How do New Zealand firms internationalize?

2) How does the internationalization of New Zealand firms compare to mainstream research?

3) What (if anything) about the New Zealand context distinguishes this research from extant knowledge?

Question (1) is the primary focus; a systematic literature review dissects how New Zealand firms internationalize. Question (2) sets the findings within the broader discourse of internationalization, while question (3) provides nuanced interpretation based on reflective remarks by scholars who have contributed to the research stream.

\section{Background}

A series of highly publicized trade development policies (i.e., Building Export Markets 2012, Trade Agenda 2030, and Trade for All Agenda) promulgated post-Global Financial Crisis (see Section 3 for an overview), suggest New Zealand is looking toward exports for sustained economic prosperity. The active participation of SMEs, which constitute $95 \%$ of all businesses, is integral to this pursuit (Ministry of Business Innovation \& Employment, 2017; Yu \& Lindsay, 2016). Statistics New Zealand's Business Operations Survey indicates $26 \%$ of New Zealand firms earn income from overseas sales. The pattern is consistent regardless of the threshold (e.g., micro, SME, large SME) used for the categorization (Statistics New Zealand, 2016).

The shift in SME policy toward an entrepreneurial economy has helped broaden New Zealand's comparative advantage beyond commodities while magnifying the importance of entry into global value chains (Jurado \& Battisti, 2019; Measson \& Campbell-Hunt, 2015; New Zealand Institute of Economics Research, 2009; New Zealand Treasury, 2014). Further, a small domestic market and low demand, combined with the allure of better opportunities for growth and market share in foreign markets, suggest INZFs adopt international expansion for market seeking reasons (Chabowski et al., 2018; Dunning, 1993; Leonidou, Katsikeas, Palihawadana, \& Stavroula Spyropoulou, 2007). They achieve higher levels of productivity, create better paying jobs, and earn foreign currency, making them a vital $\operatorname{cog}$ in driving economic growth (Casey \& Hamilton, 2014; Kahiya \& Dean, 2016). Understanding the specifics of such international expansion is fundamental, not only in the New Zealand setting, but also to internationalization research. This review identifies, integrates, and synthesizes literature with the goal of developing a cogent body of knowledge.

This systematic review is critical for four key reasons. First, it maps the state of knowledge on INZFs to develop a model on internationalization from a SMOPEC setting. Second, it benchmarks this knowledge against extant literature to underscore the uniqueness of the SMOPEC context. Third, it draws out nuance using reflective comments from key authors who have contributed to this research stream. Finally, it outlines implications for policymakers charged with fostering trade. The review adopts a systematic evidence-based approach (see Greenhalgh et al., 2005; Jones \& Gatrell, 2014; Pawson, Greenhalgh, Harvey, \& Walshe, 2005; Tranfield, Denyer, \& Smart, 2003) to search, code, organize, and synthesize literature.

\subsection{Literature search}

It is imperative to distinguish internationalization from exporting. Johanson and Vahlne (1977, p. 23) view internationalization as the "process in which the firms gradually increase their international involvement" whereas Etemad (2004, p. 4) describes it as "the general outward movement of a firm's activities". This differs from exporting research, which addresses "selling products/services via direct and/or indirect methods to overseas markets using the firm's production facilities in its home country" (Leonidou, Katsikeas, \& Coudounaris, 2010, p. 79). With a few exceptions (e.g., Ribau et al., 2018) most reviews on the international expansion of firms address 'exporting' (see Leonidou \& Katsikeas, 2010; 
Wheeler et al., 2008). Yet 'export-focused research' is narrow in scope as it may disregard establishment-, market entry-, or market servicing-, modes. This review addresses the more-inclusive term - 'internationalization', which embraces "the ongoing development and change in the international firm in terms of scope, business idea, action orientation, organizing principles, nature of managerial work, dominating values and converging norms" (Melin, 1992, p. 101).

\subsubsection{Search terms and databases}

An initial search focused on databases of ABI Inform, JSTOR, Science Direct and publisher specific platforms - Emerald, Palgrave, Sage, Springer, Taylor and Francis, and Wiley-Blackwell. Search terms included 'internationalization' and 'New Zealand firms', 'internationalization' and 'New Zealand', 'international operations' and 'New Zealand firms'. However, because the use of the term 'internationalization' only became widespread in the mid-1990's, the study included the search terms 'exporting' and 'New Zealand' and 'New Zealand exporters' to identify relevant research published prior to this. One hundred and fourteen peer-reviewed articles, published in English, were uncovered through this approach.

\subsubsection{Criteria for inclusion for further analysis}

Articles included for further analysis meet the criteria for pertinence to, and coherence with research objective(s), as follows:

1) Investigate internationalization at the firm level.

2) Examine internationalization as 'outward movement' from New Zealand.

3) Include a clear description of the fieldwork and the results deriving thereof.

Excluded from this review is literature on international trade (e.g., shift-share analysis or exchange rate pass-through effects), studies focusing on SMEs with no clear reference to international operations, and conceptual papers on internationalization authored by New Zealandbased scholars, whose data are not drawn from New Zealand (e.g., Brownie \& Dalziel, 1993; Kahiya, 2017; Mehrtens, Cragg, \& Mills, 2001). The resultant sample comprises 95 peer-reviewed journal articles published in English. It compares favorably to reviews focusing on specific contexts (see Caputo et al., $2016-\mathrm{n}=30$; Da Rocha \& Christensen, 1994 - n = 27; Deng, $2012-\mathrm{n}=121$; Ibeh et al., 2012 $\mathrm{n}=54$; Wheeler et al., $2008-\mathrm{n}=33$ ).

\subsection{Data extraction and coding}

Recent reviews on internationalization (e.g., Kahiya, 2018; Martineau \& Pastoriza, 2016) provided an initial catalogue of primary and attribute codes. These codes pertained to the bibliometric attributes (i.e., authorship, year of publication, publication outlet), and research design and methods (i.e., research setting, data collection, sample size/ response rates, and analysis). Two experienced researchers, who had published on SME internationalization participated in coding. One researcher had published on New Zealand firms, while the other had studied SMEs from several regions of the world. Working independently, the coders read an identical set of 15 randomly selected papers, before transcribing bibliometric and methodological properties onto the coding sheets. Inter-rater reliability ranged between 0.86 and 0.93, which was considered adequate for initial coding. Disagreements and inconsistencies were ironed out through discussion, which led to a refinement of some codes. The refined codes and coding protocol were applied to the remaining 80 studies. Appendix A provides detailed results of the coding process, while the subsequent section discusses descriptive results deriving thereof.

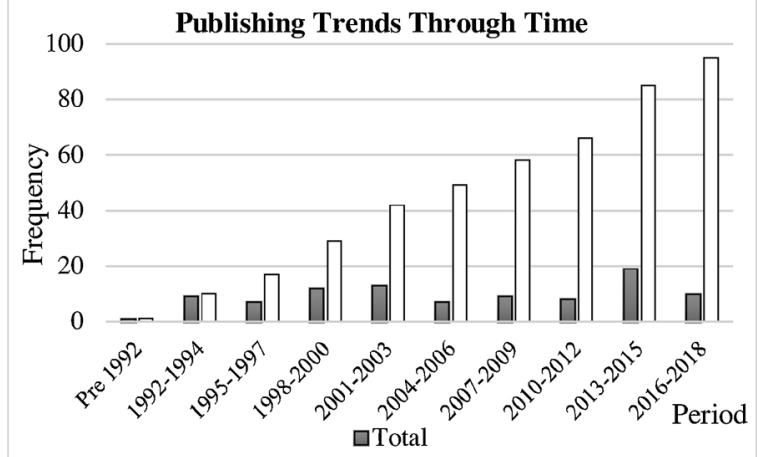

Fig. 1. Publishing Trends through Time.

\section{Descriptive results}

The study utilizes an author-centric mapping approach to provide a bibliometric synopsis of research to date, before shifting to a conceptcentric method to depict the methodological profile of the research (Greenhalgh et al., 2005; Webster \& Watson, 2002). The research setting and methodology are vital given they influence the knowledge content (Edmondson \& McManus, 2007; Reynolds, Simintiras, \& Diamantopoulos, 2003).

Further, the review identified 17 key authors contributing multiple papers to this stream of research. Email was chosen as the method of contact. Of the 15 contacted (current contact details were not available for two authors), 13 responded. Adopting an approach inspired by Delphi techniques (see Linstone \& Turoff, 1975) the review sought responses to the following three questions;

a) What motivated you to study internationalizing New Zealand firms?

b) How vital is/was context in your research on internationalization of New Zealand firms?

c) In studying New Zealand firms, did you presume/hypothesize your findings would differ from extant knowledge?

Excerpts of their remarks are included in the discussion of publication trends, theory, and ultimately, what sets apart INZFs from mainstream research.

\subsection{Profile of the studies}

\subsubsection{Publication trends}

Fig. 1 shows the publishing trends through time. The initial momentum for this stream of research stems from changes in the regulatory environment. Professor Peter Enderwick explains; "The main reason was the change in the economic environment. Following deregulation and liberalization NZ moved from being one of the most restrictive, to a much more open economy. I was interested in understanding how NZ firms would react to the changes".

In response Akoorie, Barber, and Enderwick (1993) studied the impact on New Zealand exporters, of a single-market European Community (EC), while Gray (1994) examined international strategies of recently deregulated firms. Looking back, the job losses economic deregulation precipitated motivated lifestyle entrepreneurship, typified by limited ambition and a focus on 'boat, batch, and BMW' (Baker, 2009; Jurado \& Battisti, 2019). Further, Competitive Advantage New Zealand (CANZ), a research programme initiated in 1998 to study the rise of 'world-class enterprises from a New Zealand base', may have played a catalytic role in sustaining the momentum beyond year $2000^{3}$.

\footnotetext{
${ }^{3}$ See https://www.victoria.ac.nz/som/researchprojects/research-projects/ competitive-advantage/research-overview
} 
Table 1

Leading Outlets for Research on INZFs.

\begin{tabular}{|c|c|c|}
\hline Journal & \# & Articles \\
\hline European Journal of Marketing & 12 & $\begin{array}{l}\text { Akoorie et al. (1993); Gray (1994); Coviello and Munro (1995); Chadee and Mattsson (1998); Thirkell and Dau (1998); } \\
\text { Chetty (1999); Chetty and Campbell-Hunt (2003a); Agndal and Chetty (2007); Chung (2009); Chetty and Stangl (2010); } \\
\text { Chetty et al. (2015); Chung and Kuo (2018) }\end{array}$ \\
\hline International Business Review & 9 & $\begin{array}{l}\text { Akoorie (1993); Coviello and Munro (1997); Chetty and Holm (2000); Robertson and Chetty (2000); Chetty and Wilson } \\
\text { (2003), Chung and Tung (2013), Gerschewski and Xiao (2015); Odlin and Benson-Rea (2017); Pellegrino and McNaughton } \\
\text { (2017) }\end{array}$ \\
\hline International Marketing Review & 6 & $\begin{array}{l}\text { Enderwick and Akoorie (1994); Evers and Knight (2008); Chung (2012); Chung et al. (2012); Souchon et al. (2015); Gao } \\
\text { et al. (2016) }\end{array}$ \\
\hline International Small Business Journal & 6 & $\begin{array}{l}\text { Caughey and Chetty (1994); Chetty and Hamilton (1996); Osborne (1996); Chetty and Campbell-Hunt (2003b); Gerschewski } \\
\text { et al. (2018); Sadeghi et al. (2018) }\end{array}$ \\
\hline Journal of International Entrepreneurship & 5 & Shaw and Darroch (2004); Coviello and Cox (2006); Kahiya (2013); Kahiya et al. (2014); Casey and Hamilton (2014) \\
\hline Journal of International Marketing & 5 & $\begin{array}{l}\text { Coviello and Martin (1999); Chung (2003); Chetty and Campbell-Hunt (2004); Chetty and Agndal (2007); Vasilchenko and } \\
\text { Morrish (2011) }\end{array}$ \\
\hline Journal of Small Business Management & 4 & Au and Enderwick (1994); McGregor and Gomes (1999); Hamilton and Dana (2003); Yu and Lindsay (2016) \\
\hline Asia Pacific Journal of Marketing of Logistics & 4 & Deng et al. (1995); Chung (2007); Kahiya and Dean (2014), 2015 \\
\hline Journal of Asia-Pacific Business & 3 & Chung (2002); Sinha and Akoorie (2010); Jin and Hurd (2018) \\
\hline Asia Pacific Journal of Management & 2 & Akoorie and Enderwick (1992); Chung and Enderwick (2001) \\
\hline Journal of International Business Studies & 2 & Gray (1997); Coviello (2006) \\
\hline Journal of Strategic Marketing & 2 & Chetty and Hamilton (1993); Chetty and Patterson (2002) \\
\hline Journal of World Business & 2 & Loane et al. (2007); Gerschewski, Rose, and Lindsay (2015) \\
\hline Management International Review & 2 & Hoang (1998); Pellegrino and McNaughton (2015) \\
\hline Marketing Intelligence and Planning & 2 & Crick and Crick (2015); Crick and Lindsay (2015) \\
\hline Other $^{\mathrm{a}}$ & 29 & e.g. Dean et al. (2000); Bell et al. (2001) $)^{\mathrm{ii}}$, Cadogan et al. (2001) \\
\hline
\end{tabular}

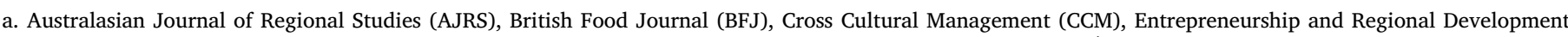

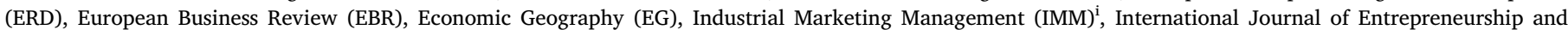

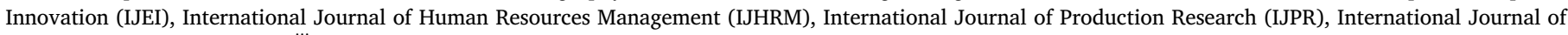

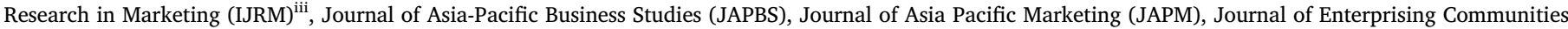

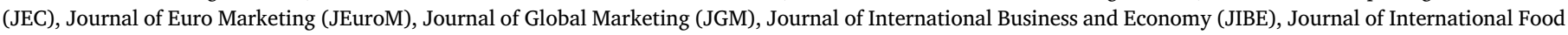

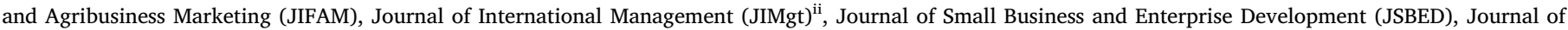

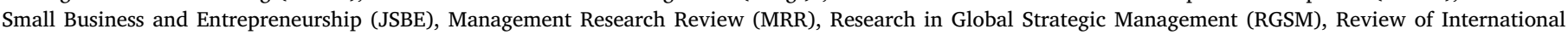
Business and Strategy (RIBS), Regional Studies, (RS), Small Enterprise Research (SER).

The surge in publications between 2013 and 2015 probably traces to the post-Global Financial Crisis endeavor to grow exports. Building Export Markets 2012, is a useful case in point. This national export strategy (NES) aimed to grow exports to $40 \%$ of the gross domestic product by 2025. Repackaged in 2017 as Trade Agenda 2030, the NES has adopted a new goal - ensuring 95\% of New Zealand's merchandise exports are covered by free trade agreements by 2030 (New Zealand Government, 2017). Appendix B provides an abridged version of Building Export Markets 2012 and Trade Agenda 2030.

Further, trade policy is now migrating to an 'inclusive' trade agenda. These changes may explain why interest appears to have tapered off in the last three years although it is likely the notion of Trade for All may pose fascinating new questions for researchers especially regarding responsible business practices. To Professor David Dean, this makes New Zealand "a naturally occurring laboratory for studying small businesses that are involved in exporting and global trade".

\subsubsection{Publication outlets}

Table 1 shows that 15 publications have disseminated nearly $70 \%$ of the research on INZFs. Four outlets in particular - European Journal of Marketing (12), International Business Review (9), and International Marketing Review/International Small Business Journal (each with six articles) -account for more than one-third of this research.

While this list of publications is consistent with recent reviews (e.g., Martineau \& Pastoriza, 2016; Park, LiPuma, \& Prange, 2015; Ribau et al., 2018), International Business Review (IBR) is the only IB journal, which has consistently published research on INZFs.

\subsubsection{Authorship}

Table 2 shows Coviello and colleagues' research on network-based internationalization, constitutes the most frequently cited collection of studies; followed by Chetty et al.'s work on stage-based and early-rapid internationalization. Bell, McNaughton, and Young's (2001) theorization of 'born-again global', is the sole study, in the top 10, featuring neither Chetty nor Coviello as author(s).

\subsubsection{Industries studied}

Thirty-one studies (e.g., Akoorie \& Enderwick, 1992; Chetty, 1999; Fabling, Grimes, \& Sanderson, 2012; Kahiya \& Dean, 2016; Loane, Bell, \& McNaughton, 2007; Measson \& Campbell-Hunt, 2015) examine manufacturing firms. Nineteen focus on a single sector within the manufacturing industry. Wine (e.g., Crick \& Crick, 2015; Felzensztein, Stringer, Benson-Rea, \& Freeman, 2014; Morrish \& Deacon, 2011; Sinha \& Akoorie, 2010; Yu \& Lindsay, 2016) and high tech manufacturing (e.g., Chetty \& Wilson, 2003; Coviello \& Munro, 1995; Coviello \& Munro, 1997; Pellegrino \& McNaughton, 2017) are the most prominent sectors.

Twenty-four studies (e.g., Battisti \& Perry, 2008; Chadee \& Mattsson, 1998; Chetty, Ojala, \& Leppäaho, 2015; Chung \& Kuo, 2018; Deng, Duffy, \& Harrison, 1995) combine manufacturing and service industry, while a smaller cluster focuses on the service industry. Service sectors covered embrace consulting, information technology, and media (see Coviello \& Martin, 1999; Gao, Ren, Zhang, \& Sun, 2016; Gray, 1994). The remaining studies are either conceptual or do not indicate industry.

\subsubsection{Research design and method}

To assess the research design and methods, the study uses four dichotomies; quantitative/qualitative, cross-sectional/longitudinal, single country/cross-national, and single method/mixed method. The single largest design/methods cluster encompasses 28 cross-sectional quantitative empirical studies (e.g., Chung \& Kuo, 2018; Dean, Mengüç, \& Myers, 2000; Hoang, 1998; Le Heron, 1980; Sadeghi, Rose, \& Chetty, 2018; Sinha \& Akoorie, 2010; Yu \& Lindsay, 2016). Postal surveys (see Casey \& Hamilton, 2014; Chung, 2009; Corbett, 1996) are the most common method of data collection. Analytical tools include basic multivariate statistics [e.g., $\mathrm{t}$ tests, analysis of variance (ANOVA), principal component analysis (PCA), and regression]. Cross-sectional 
Table 2

The Ten Most Cited Studies.

\begin{tabular}{|c|c|c|c|c|c|}
\hline Rank & Author(s) & Total Citations & Rank & Author(s) & Citations per year* \\
\hline 1 & Coviello \& Munro, 1997 & 1729 & 1 & Coviello, 2006 & 86 \\
\hline 2 & Coviello \& Munro, 1995 & 1335 & 2 & Coviello \& Munro, 1997 & 82 \\
\hline 3 & Coviello, 2006 & 1031 & 3 & Coviello \& Munro, 1995 & 58 \\
\hline 4 & Chetty \& Holm, 2000 & 839 & 4 & Chetty \& Campbell-Hunt, 2004 & 56 \\
\hline 5 & Chetty \& Campbell-Hunt, 2004 & 787 & 5 & Chetty \& Holm, 2000 & 47 \\
\hline 6 & Bell et al., 2001 & 657 & 6 & Bell et al., 2001 & 39 \\
\hline 7 & Coviello \& Martin, 1999 & 437 & 7 & Chetty \& Campbell-Hunt, 2003a & 26 \\
\hline 8 & Chetty \& Campbell-Hunt, 2003a & 395 & 8 & Coviello \& Martin, 1999 & 23 \\
\hline 9 & Chetty \& Wilson, 2003 & 334 & 9 & Chetty and Wilson & 22 \\
\hline 10 & Chetty \& Campbell-Hunt, 2003b & 304 & 10 & Chetty \& Campbell-Hunt, 2003b & 20 \\
\hline
\end{tabular}

${ }^{\#}$ Based on Google Scholar (17/08/2018) * Current year (2018) minus year of publishing.

qualitative research is the second largest cluster (see Caughey \& Chetty, 1994; Crick \& Crick, 2015; Measson \& Campbell-Hunt, 2015; Morrish \& Deacon, 2011; Vasilchenko \& Morrish, 2011) and accounts for $28 \%$ of the research. The cluster includes both single (e.g., Chetty \& Patterson, 2002; Gao et al., 2016) and multiple (e.g., Chetty \& Hamilton, 1993; Odlin \& Benson-Rea, 2017; Sternad, Jaeger, \& Staubmann, 2013) case study approaches. Manual coding, pattern matching, and explanation building are the preferred analytical approaches (e.g., Chetty \& Stangl, 2010; Coviello \& Cox, 2006; Sedoglavich, 2012). Overall, the longitudinal/cross-sectional and quantitative/qualitative dichotomies account for the majority (i.e., 56 out of 95) of the studies.

The remaining 39 studies depict research design and methodological plurality uncommon to extant literature on internationalization. Indeed, multiple scholars (e.g., Coviello \& Jones, 2004; Li et al., 2017; Paul \& Rosado-Serrano, 2019) reviewing literature on internationalization/exporting indicate the lack of diversity in methodology is hampering this domain. Akoorie et al. (1993) and Hamilton and Dana (2003) combine insights from market trends, macro-level data, and expert opinion to articulate the impact of the then EC on New Zealand exporters, and the increasingly important role SMEs play in fostering export growth, respectively. Six studies (e.g., Chetty \& Campbell-Hunt, 2004) adopt a qualitative longitudinal design, whereas five (e.g., Kahiya \& Dean, 2015; Kahiya, Dean, \& Heyl, 2014) utilize a longitudinal quantitative empirical approach. Another two cross-sectional and two longitudinal studies employ mixed methods (see Gray, 1994; McGregor \& Gomes, 1999).

Nineteen studies encompass cross-national samples, and of these, seven (e.g., Agndal \& Chetty, 2007; Gerschewski, Lindsay, \& Rose, 2016) are cross-sectional qualitative; nine (e.g., Chung \& Tung, 2013; Souchon, Dewsnap, Durden, Axinn, \& Holzmüller, 2015) cross-sectional quantitative; and three (e.g., Gerschewski \& Xiao, 2015) cross-sectional mixed methods. These studies are analytically robust. For instance, Gerschewski et al. (2016) supplement manual coding with automated content analysis, using Nvivo, while Chung and Tung (2013) and Souchon et al. (2015) employ advanced multivariate techniques like structural equation modelling/path analysis. The foregoing synopsis offers glimpses on the diverse contexts (e.g. media/broadcasting, generic manufacturing, and recently deregulated SOEs) and methodological plurality (e.g., quantitative/qualitative, cross-national, longitudinal, and conceptual) prevalent in research on INZFs. Remarks by two researchers identify potential factors that may underpin this plurality. Professor Arthur Grimes contends; "One benefit of studying NZ firms (including exporters) is that our micro data on firms (via Statistics NZ's Longitudinal Business Database - LBD) is amongst the most comprehensive in the world, linking data from taxes, government surveys, customs records, etc. This makes detailed empirical work on NZ firms possible and potentially at the forefront of firm-related research internationally".

Professor Nicole Coviello explains; "An additional asset (again unplanned but useful) was that I was able to access the entire software industry of NZ in one fell swoop". Thus, it appears primary data were relatively easy to collect at the time of Professor Coviello's research.
The subsequent section addresses key theories and paradigms before shifting to a discussion of the variables and knowledge content of the literature.

\subsection{Theories and paradigms}

Research on INZFs employs the resource-based view, incrementalstage internationalization, early-rapid paradigm, social capital- and learning theories. Each of these theories is discussed in the subsequent section. The review also acknowledges potentially useful but underutilized perspectives (i.e., entrepreneurial marketing, and effectuation and causation). Emeritus Professor Bob Hamilton reiterates that "...at the outset the research focus was driven by changes in the institutional environment (deregulation and trade liberalization). The theoretical development came later"

\subsubsection{Resource-based view}

Outside of the institutional perspective, few theories have commanded more research attention among IB scholars, than the resource-based view (RBV). [Refer to Kraaijenbrink, Spender, and Groen (2010) for a detailed appraisal of RBV]. Scholars study both resource proxies (e.g., firm size, experience) and actual (i.e., tangible and intangible) resources like patents, research and development budgets or managerial acumen (Barney, 2001; Dhanaraj \& Beamish, 2003; İpek, 2018). Several studies on INZFs (e.g., Akoorie \& Enderwick, 1992; Dean et al., 2000; Kahiya \& Dean, 2014; Le Heron, 1980; Loane et al., 2007; Osborne, 1996) use RBV to explain the importance of resources (and capabilities) to strategy and performance.

\subsubsection{Incremental/stage-based internationalization}

Incremental internationalization advances that international involvement culminates in a sequential approach to market expansion characterized by increasing commitment (Johanson \& Vahlne, 1977; Johanson \& Wiedersheim-Paul, 1975). It explains why initial involvement may commence with (in)direct exports before shifting to highresource high-risk modes. Early research (e.g., Bilkey, 1978; Bilkey \& Tesar, 1977) on the international operations of USA exporters adopted this perspective to inform the innovation adoption stages of internationalization (see Czinkota \& Johnston, 1981). Thus incremental internationalization takes two forms, the Uppsala model and innovation adoption (stage models). Research on INZFs (e.g., Dean, Gan, \& Myers, 1998; Kahiya \& Dean, 2016) utilizes the latter version of incremental internationalization. In-spite of the criticism of stage models (see, Andersen, 1993; Bell, 1995), some researchers (e.g., Uner, Kocak, Cavusgil, \& Cavusgil, 2013; Wickramasekera \& Oczkowski, 2006) consider them a useful typology for profiling internationalizing firms.

\subsubsection{Early-rapid internationalization}

Oviatt and McDougall (1994) present international new ventures (INVs) as a counter-narrative to traditional incremental internationalization. Unlike the Uppsala model, which depicts international 
involvement as evolutionary; they see it as 'revolutionary' in that firms had high levels of commitment to overseas markets, electing to derive a significant percentage of sales turnover from international proceeds. Around the same time a report by McKinsey (see Rennie, 1993) described born-global firms as a new breed of exporters on the world stage. Because growth-focused New Zealand SMEs often look to early and rapid internationalization as an option, this paradigm is relevant to INZFs. A sizeable share of research on INZFs (e.g., Coviello \& Cox, 2006; Gerschewski \& Xiao, 2015; Kahiya, 2013; Odlin \& Benson-Rea, 2017; Pellegrino \& McNaughton, 2015; Sinha, Wang, Scott-Kennel, \& Gibb, 2015) examines the international forays of omnipresent INVs and BGs.

\subsubsection{Learning}

Levitt and March (1988, p. 319) view learning as the mechanism through which organizations encode "inferences from history into routines that guide behavior". Increasingly, learning and knowledge acquisition, have emerged as a focal point of internationalization (see reviews by De Clercq, Sapienza, Yavuz, \& Zhou, 2012; İpek, 2019; and Park et al., 2015). De Clercq et al. (2012) identify five forms of organizational learning - experiential, vicarious, congenital, grafting, and searching pertinent to internationalization. Of particular import to their review is congenital learning, which they suggest portrays the divergent premises from which traditional/incremental and early/rapid internationalization stem. The adoption of the learning perspective to study INZFs is recent (see Crick \& Crick, 2015; Gerschewski, Lew, Khan, \& Park, 2018; Pellegrino \& McNaughton, 2015, 2017) and appears to be motivated, at least in part, by the aforementioned reviews.

\subsubsection{Social capital}

Adler and Kwon (2002, p. 17) define social capital "as the goodwill that is engendered by the fabric of social relations and that can be mobilized to facilitate actions". Because, broadly, social capital impacts the nature of interactions between social actors, it influences success rates in a job search, career success, resource exchanges between business units, and strengthens relationships with suppliers (Adler \& Kwon, 2002). Internationalizing firms benefit from the social capital developed across their value chains (see Johanson \& Mattsson, 2015). This includes macro (e.g., governmental bodies, trade associations, commercial banks, transportation and logistics providers) and micro environmental (e.g., suppliers, distributors, competitors, customers) participants (Freeman, Edwards, \& Schroder, 2006; Sharma \& Blomstermo, 2003). Networks provide an insider position in markets, create/leverage resources and act as a source of vicarious learning (Ghauri, Lutz, \& Tesfom, 2003; Manolova, Manev, \& Gyoshev, 2010). Countless studies on INZFs (e.g., Chetty \& Stangl, 2010; Chetty \& Wilson, 2003; Coviello, 2006; Coviello \& Munro, 1995; Gao et al., 2016; Leppäaho, Chetty, \& Dimitratos, 2018) utilize this slant.

\subsubsection{Other theories and paradigms}

It is important to highlight other potentially useful perspectives that have been employed to a lesser extent. Entrepreneurial marketing (EM), a construct which blends the marketing concept and entrepreneurial orientation (see Morris, Schindehutte, \& LaForge, 2002) should apply to the marketing initiatives of smaller and potentially resource-constrained INZFs. However, Morrish and Deacon (2011) are the lone study which draws from the EM construct. Entrepreneurial contingency (i.e., effectuation and causation) can inform research on INZFs (see Sarasvathy, 2001). For instance, effectuation takes the suite of means available (i.e., resources) as a given, then focuses on creating appropriate effects (i.e., outcomes) using those means (Sarasvathy, 2001). Resource-deprived INZFs may start off with finite means from which they create effects such as strategy or performance. Crick and Crick (2015) adopt this view to investigate decision-making processes in INZFs.

Thus, both traditional and emergent theories of internationalization are applicable to INZFs. Referring primarily to studies conducted in the 1980's and 90's, Professor Peter Enderwick emphasizes that "Existing theory was applicable but we had to consider the small average size of $N Z$ firms, their focus on exporting and weak managerial resources. Otherwise OLI and process models were relevant'. However, because International Entrepreneurship (IE) emerged in the early 1990's, when research on INZFs was taking off, the IE field has helped shape literature on INZFs. This aspect is not lost on Professor Nicole Coviello who outlines; "As it turns out, the timing of my research was such that it was the beginning of research in international entrepreneurship".

\section{Clusters and indicator variables}

A concept-centric approach, embracing the tenets of historicity, plurality, and contestation, organized knowledge into a series of primary and secondary categories (see Salipante, Notz, \& Bigelow, 1982; Torraco, 2005). Historicity pertains to temporal context; plurality acknowledges diversity/complexity in methods and procedures; and contestation reflects the willingness to accept ambiguity and conflicting ideas (Greenhalgh et al., 2005; Salipante et al., 1982; Torraco, 2005).

Data extraction and coding of relationships followed a process analogous to that detailed in Section 2.2. First, the variables were coded separately and cross-checked against past reviews (e.g., Canabal \& White, 2008; Li et al., 2017; Park et al., 2015; Wheeler et al., 2008) to enhance reliability and validity. Subsequently, for each of the studies, the coded variables were classified as independent and dependent variables to map the relationships. The linkages emerged deductively from this process. This approach is comparable to recent studies (e.g., Keupp \& Gassmann, 2009; Martineau \& Pastoriza, 2016; Park et al., 2015) on internationalization.

The major theoretical contribution of this review arises from the conceptual model in Fig. 2 and the detailed exposition of the research linkages. The remainder of this section provides an overview of each of the main categories - antecedents, stimuli, capabilities, strategy, process, and outcomes followed by a discussion of the linkages among the specific variables. Macro level outcomes, which will not be discussed as part of the main model, are included to emphasize the impact INZFs have on productivity, employment, and economic prosperity.

\subsection{Antecedents}

Antecedents set the platform for onward internationalization (Martineau \& Pastoriza, 2016). Literature (e.g., Akoorie \& Enderwick, 1992; Dana, 2003; Le Heron, 1980; Osborne, 1996; Sinha \& Akoorie, 2010) identifies three broad categories; managerial, environmental, and firm-level factors. Managerial factors comprise age, language skills, international experience, and export immigrant effect, whereas firmlevel factors encompass size, age, ownership, sector and export experience. Thus firm- and managerial-level antecedents are predominantly demographic in nature. Further, the quality of the business environment, in particular, competition, policy, and regulations set the stage for international expansion.

\subsection{Stimul}

Expansion stimuli (ES) provoke the initial decision to internationalize and the likelihood of successful ongoing international expansion (Leonidou et al., 2007). They embrace motives, barriers, unsolicited orders, participation in trade shows, free trade agreements, and export support (Au \& Enderwick, 1994; Battisti \& Perry, 2008; Measson \& Campbell-Hunt, 2015). Nearly half of the research (e.g., Alon, Dana, \& Jenkins, 2009; Au \& Enderwick, 1994; Battisti \& Perry, 2008; Evers \& Knight, 2008; Gray, 1997; Thirkell \& Dau, 1998) on expansion stimuli addresses what Caughey and Chetty (1994) term preexport behavior. 


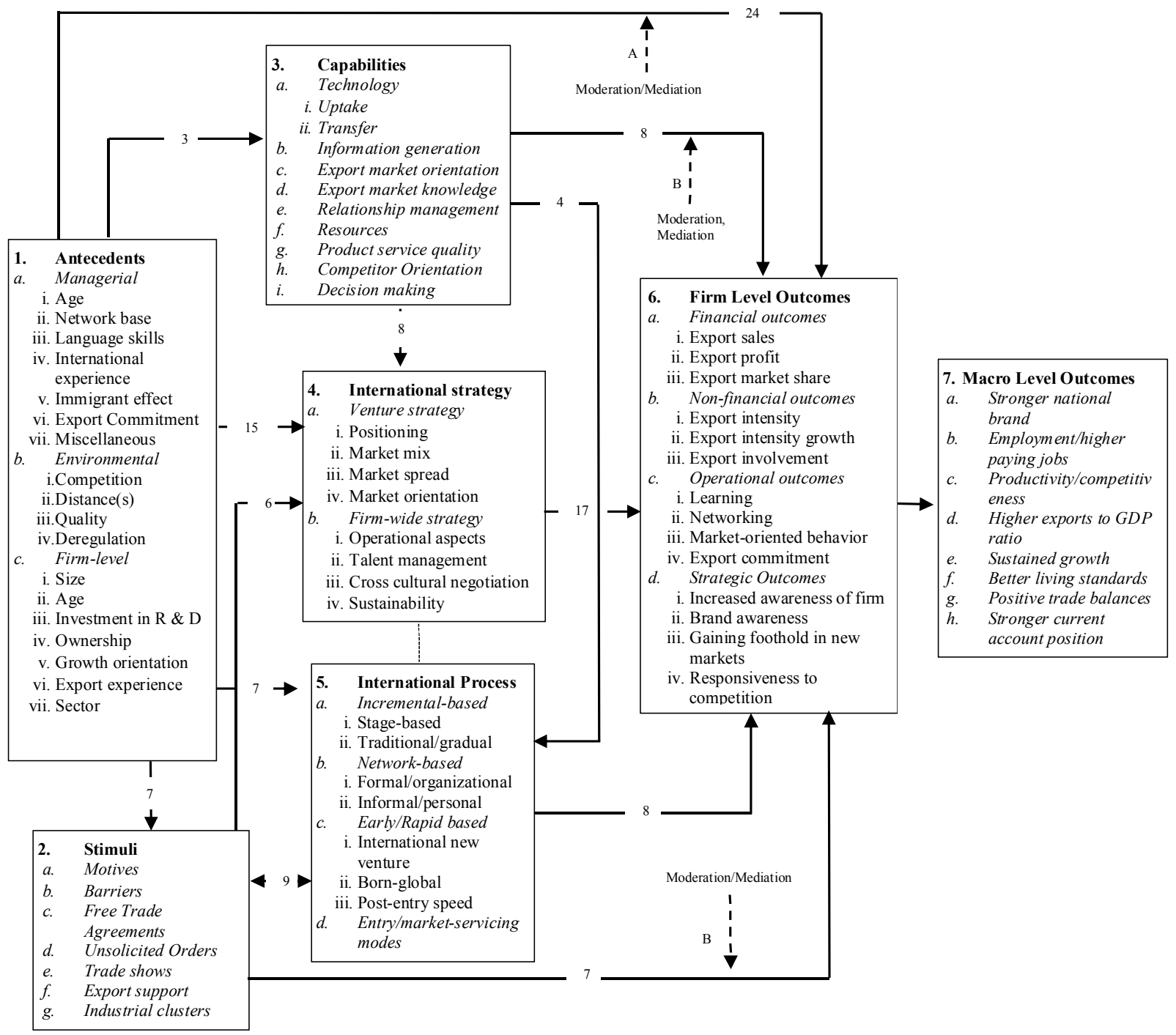

Fig. 2. Conceptual Model on Internationalization from a Small Open Economy - Variables and Codes.

\subsection{Capabilities}

Capabilities are valuable organizational routines and bundles of resources, which enable strategy and facilitate survival and growth (İpek, 2018; Prange \& Verdier, 2011; Sapienza, Autio, George, \& Zahra, 2006; Tallman \& Fladmoe-Lindquist, 2002). Prange and Verdier (2011) distinguish generic threshold and consolidation capabilities (i.e., required for survival) from value-adding and disruptive capabilities, which facilitate growth. Concerning INZFs, commonly researched capabilities encompass technology, information generation, export market knowledge/orientation, relationship management, product/service quality, competitor orientation, and decision-making (see Chadee \& Zhang, 2000; Chetty \& Hamilton, 1993; McGregor \& Gomes, 1999; Morrish \& Deacon, 2011; Souchon \& Durden, 2003; Sternad et al., 2013). These capabilities reflect both a survivalist- and a growth-focus in the orchestration of international activities.

\subsection{Strategy}

International strategy denotes plans of action and initiatives designed to enhance the competitiveness of internationalizing firms. It is one of the most exhaustively researched areas (see Agndal \& Chetty, 2007; Akoorie \& Enderwick, 1992; Akoorie et al., 1993; Battisti, Jurado, \& Perry, 2014; Chetty \& Wilson, 2003; Chung, 2002; Corbett,
1996; Enderwick \& Hodgson, 1993; Enderwick \& Ronayne, 2004; Fabling et al., 2012; Gray, 1994; Hamilton \& Dana, 2003; Sedoglavich, 2012; Souchon et al., 2015). This review distinguishes venture-level customer-facing strategies from firm-wide (mostly) inward-looking initiatives. The former (e.g., Dean et al., 2000; Hoang, 1998; Morrish \& Deacon, 2011; Souchon et al., 2015) cover a spectrum ranging from entry-related aspects to modification of the marketing mix, whereas the latter (see Corbett, 1996; Enderwick \& Hodgson, 1993; Sinha \& Akoorie, 2010; Stark, Fam, Waller, \& Tian, 2005) encompass operational aspects like talent management, sustainability, and cross-cultural negotiation. It is likely entry into global value chains will become a far more strategic initiative than the normative considerations of standardization and adaptation (Jurado \& Battisti, 2019; Measson \& CampbellHunt, 2015; New Zealand Treasury, 2014).

\subsection{Process}

The international process refers to the pattern of decisions and activities regarding, speed, scale and scope, which unfolds with international expansion (Welch \& Paavilainen-Mäntymäki, 2014). Research on the process INZFs adopt originates from the mid-1990s, and from the outset two paradigms (i.e., early-rapid and stage-based incremental) internationalization emerged (e.g., Chetty, 1999; Chetty \& Hamilton, 1996; Coviello \& Munro, 1995; Chetty \& Hamilton, 1996; Deng et al., 
1995). Bell et al. (2001) offer a different slant to the notion of earlyrapid internationalization. They designate born-again globals as INZFs with a long incubation period (within their home market), which is succeeded by a rapid increase in the international footprint.

\subsection{Outcomes}

The review identifies four categories of outcomes; financial performance metrics, non-financial performance metrics, operational, and strategic (marketing) outcomes. Financial (e.g., sales, profit, and market share), and non-financial (e.g., export intensity, export involvement) performance indicators are the most frequently researched (see Casey \& Hamilton, 2014; Chadee, 2004; Chadee \& Mattsson, 1998; Chadee \& Zhang, 2000; Chung, 2012; Dean et al., 2000; Enderwick \& Akoorie, 1994; Fabling et al., 2012; Gerschewski \& Xiao, 2015; Hoang, 1998; Kahiya \& Dean, 2014; Robertson \& Chetty, 2000; Thirkell \& Dau, 1998). There is an emerging body of research (see Felzensztein et al., 2014; Gao et al., 2016; Morrish \& Deacon, 2011; Pellegrino \& McNaughton, 2015; Pellegrino \& McNaughton, 2017; Yu \& Lindsay, 2016) investigating operational factors (e.g., commitment, networking capability, and learning) and strategic outcomes (e.g., brand awareness, interfirm collaboration, new market development, and market responsiveness) of international expansion.

\section{Synthesis: exploring the linkages}

The six categories - antecedents, stimuli, capabilities, process, strategy, and outcomes - depicted in Fig. 2 are the foundation of the discussion below. For each primary category, key factors are identified and each factor is decomposed by the specific variable used to test relationships. Numbers in the connecting arrows depict how frequently the linkage has been explored.

\subsection{Antecedents and stimuli, linkage 1-2}

Seven studies (i.e., Chadee \& Mattsson, 1998; Chetty et al., 2015; Crick \& Crick, 2015; Dana, 2003; Kahiya \& Dean, 2015; Kahiya et al., 2014; Shaw \& Darroch, 2004) probe the relationship between antecedents and a specific type of stimulus - barriers. Managerial sociocognitive attributes are the foremost element underlying the influence of barriers (Crick \& Crick, 2015; Gray, 1994; Kahiya \& Dean, 2015; Kahiya et al., 2014). For instance, managers with an 'achiever' mentality are more likely to downplay the effect of barriers than those with a pessimistic view (Gray, 1997). Likewise, 'achievers' are more likely to value proactive instead of reactive stimuli. Perception of costs and risks depends on whether owner-managers are running the INZF to maintain a lifestyle or foster growth (Crick \& Crick, 2015). Further, a deteriorating business environment, or the mere perception of it amplifies the influence of export barriers (Kahiya \& Dean, 2015; Kahiya et al., 2014).

Dana (2003) uses the travails of INZFs operating from the Chatham Islands - a $960 \mathrm{~km} 2$ archipelago located $800 \mathrm{~km}$ east of Christchurch, to capture the tyranny of geographic distance. New Zealand's location in the Pacific places it far from most markets, and an even more remote location like the Chatham Islands, aggravates the situation. Costly, nonvalue added transportation services on offer, continue to erode the long-term competitiveness and viability of exporting from the Chatham Islands (Dana, 2003). Shaw and Darroch (2004) adopt a resource-based explanation to highlight an inverse relationship between firm size and barriers.

\subsection{Antecedents and capabilities, linkage 1-3}

Crick and Lindsay (2015), Hamilton and Dana (2003), and Sinha et al. (2015) explore antecedents to capabilities. Crick and Lindsay (2015) underscore the importance of macro-level government assistance including building image and reputation, representation in overseas markets, help with information and networking, and staffing and resourcing issues. Hamilton and Dana (2003) indicate that by encouraging technological sophistication, investment in $\mathrm{R} \& \mathrm{D}$, and adoption of international orientation, the government plays a subsidiary role in capability development. Sinha et al. (2015) go further arguing that proactive exporters operating in dynamic environments are better off honing their own capabilities than relying on a third-party such as a research firm or trade development agency.

\subsection{Antecedents and strategy, linkage 1-4}

With 15 studies (e.g., Caughey \& Chetty, 1994; Chetty \& CampbellHunt, 2003a; Chung, 2002, 2003, 2007; Enderwick \& Akoorie, 1994; Enderwick \& Hodgson, 1993; Fabling et al., 2012; Hoang, 1998; Odlin \& Benson-Rea, 2017), the antecedent-strategy relationship is the third most well-researched. Enderwick and Hodgson (1993) find that New Zealand-owned INZFs see expatriation as more of a strategic issue than foreign-owned ones, while Sinha and Akoorie (2010) indicate that coercive and normative forces in the institutional environment explain the adoption of sustainability strategies among INZFs.

Initially, INZFs pursued niche and concentration strategies embracing limited commitment to international activities, narrow product line, and focus on psychically similar markets (Akoorie \& Enderwick, 1992; Enderwick \& Akoorie, 1994). Caughey and Chetty (1994) underlined the criticality of managerial proactiveness in empowering these strategies. Unsurprisingly, recently deregulated public entities were more likely to start with passive strategies as they adjust to a market-based commercial landscape, before shifting to an active or proactive approach (Gray, 1994). Nothing captures the criticality of strategy than the fact that it alters, fundamentally, the profile and structure of an internationalizing firm (Chetty \& Campbell-Hunt, 2003a; Enderwick \& Akoorie, 1994). For instance, strategy influences the choice of hierarchical or flexible structures (Enderwick \& Ronayne, 2004).

Language skills and pre-existing import relationships shape market selection decisions (Enderwick \& Akoorie, 1994; Fabling et al., 2012). For instance, INZFs gravitate toward markets for which they have language competency (Enderwick \& Akoorie, 1994). Fabling et al. (2012) illustrate a pre-existing import relationship with a specific country increases the odds of targeting that country. Host market business systems, market size of the industry, sales value, company size, differentiated products, international experience, and cultural similarity influence the choice of (a) a direct channel, (b) market expansion strategy, and (c) market mix modification (Chadee, 2004; Chung, 2002; Hoang, 1998; Osborne, 1996). Other factors have differential effects on strategy. For instance, culture has a main effect on promotion adaptation; economic differences and competition influence pricing strategy; and infrastructure effects adaptation of place/distribution (Chung, 2007, 2012). Interestingly, INZFs tend to be larger, more experienced and more adept at executing elaborate market-mix modification than their Australian counterparts (Chung, 2003, 2012).

\subsection{Antecedents and process, linkage 1-5}

Seven studies (i.e., Chetty, 1999; Chetty \& Patterson, 2002; Chung, 2012; Chung \& Enderwick, 2001; Chung \& Tung, 2013; Gerschewski et al., 2016; Loane et al., 2007) address the link between antecedents and the path, pace, and scope of international activities. Firm-level experience with a market 'a priori', the presence of immigrant social networks, and an offering which requires a high level of pre- and postsales service, lead to the choice of a higher commitment- instead of an exporting mode (Chung \& Enderwick, 2001). Other studies (e.g., Gerschewski et al., 2016; Loane et al., 2007) examine elements underpinning international new venturing among INZFs.

Sixty-percent of INVs involve two or three founders, some of whom may have worked or studied abroad (Loane et al., 2007). Further, 
networking and entrepreneurial orientation are vital to early-rapid internationalization. Gerschewski et al. (2016) illustrate that although decision-makers in rapidly internationalizing firms are not manifestly more risk-taking, they exhibit 'passion' and 'perseverance' uncommon to traditional internationalization. Likewise, Chetty and Patterson (2002) note policymaker-sponsored collaborative action group - Telecommunications Exporters of New Zealand (TENZ), expedited the formation of formal networks, which increased the speed and scope of international activities.

\subsection{Antecedents and outcomes, linkage 1-6}

With 24 studies (see Casey \& Hamilton, 2014; Chetty \& Hamilton, 1996; Dean et al., 2000; Kahiya \& Dean, 2014; Le Heron, 1980; Sinha \& Akoorie, 2010; Yu \& Lindsay, 2016), the antecedent-outcome link is the most exhaustively researched relationship. Managerial socio-cognitive factors influence both financial (Chadee, 2004; Dean et al., 2000; Enderwick \& Akoorie, 1994; Gray, 1997) and operational outcomes (Fabling \& Sanderson, 2013; Hoang, 1998; Yu \& Lindsay, 2016). For instance, high performing exporters tend to have foreign language specialists, and decision-makers in these firms exhibit an 'international achiever' mindset epitomized by a positive perception of exporting (Enderwick \& Akoorie, 1994; Gray, 1997). Further, Chadee and Mattsson (1998) find that export experience and export commitment have a positive effect, while the export destination has a negative effect on export performance.

Regarding operational outcomes, Yu and Lindsay (2016) show that commitment to exporting is subject to the dual effects of past performance and the influence of the global financial crisis. Fabling and Sanderson (2013) demonstrate that although self-selection bias and post-entry learning are relevant in explaining the productivity gap between exporters and non-exporters, the former benefit from investment decisions (i.e., labor productivity/capital) made prior to, and during the early years of entry.

Resource-related variables also influence financial outcomes (Casey \& Hamilton, 2014; Dean et al., 2000; Kahiya \& Dean, 2014). For example, export experience and firm size distinguish 'high' from 'low' export performance (Dean et al., 2000; Kahiya et al., 2014). Casey and Hamilton (2014) find that the number of export markets and R \& D intensity, have a positive effect on export performance. Le Heron (1980) advances that export promotion programmes in the 1970s, had a positive effect on the performance of manufactured exports as evidenced by increases in export intensity, and market exploitation and extension.

\subsection{Stimuli and strategy, linkage $2-4$}

Six studies (i.e., Akoorie et al., 1993; Battisti et al., 2014; Chung, 2009, 2012; Dana, Chan, \& Chia, 2008; Fabling et al., 2012) examine the connection between stimuli and strategy. Akoorie et al. (1993) observe that, faced by stiff competition from other exporters targeting the then European Community, resource-deprived INZFs relied on niche marketing. Fabling et al. (2012) find that while multi-product and multi-destination INZFs have a higher probability of expanding into additional markets, an appreciation of the New Zealand dollar has a negative effect on additional expansion. Environmental factors (i.e., market similarity between host and home country concerning politicallegal facets) lead to standardization of promotion strategy (Chung, 2009). In a follow-up study, Chung, Lu Wang, and Huang (2012) underline an analogous pattern of results. Although the lack of policymaker support limits the strategic options available for micro-enterprises (Dana et al., 2008), external stimuli like free trade agreements (FTAs) have no effect on targeting (Battisti et al., 2014).

\subsection{Stimuli and process, linkage $2-5$}

Nine studies (i.e., Au \& Enderwick, 1994; Coviello \& Martin, 1999; Coviello \& Munro, 1995, 1997; Dean et al., 1998; Evers \& Knight, 2008; Kahiya, 2013; Kahiya \& Dean, 2016; Vasilchenko \& Morrish, 2011) examine the dual connection between stimuli and the process of internationalization. Market-seeking motives explain the adoption of international joint venturing by INZFs operating in China (Au \& Enderwick, 1994); trade shows facilitate rapid international expansion (Evers \& Knight, 2008); and networks are the backbone of early-rapid internationalization (Coviello \& Munro, 1995; Coviello \& Munro, 1997). Further, the capacity of formal and informal networks to stimulate internationalization stems from the degree of embeddedness (Coviello \& Martin, 1999; Leppäaho et al., 2018).

The international process also influences perception of stimuli. For instance, Au and Enderwick (1994) warn that joint venturing is fraught with barriers (e.g., lack of familiarity with business practices, insufficient infrastructure, risk of breach of contract, and challenges in recruiting and communicating with personnel). Dean et al. (1998) and Kahiya and Dean (2016) illustrate the influence of barriers is exportstage dependent, while Kahiya (2013) notes, traditional exporters are more likely to perceive knowledge and cultural barriers as more problematic than INVs.

\subsection{Stimuli and outcomes, linkage 2-6}

Seven studies (i.e., Alon et al., 2009; Chetty, 1999; Dean et al., 2000; Enderwick \& Akoorie, 1994; Gray, 1997; Kahiya \& Dean, 2014; Measson \& Campbell-Hunt, 2015) examine the influence of stimuli on international outcomes. For example, Alon et al. (2009) indicate international involvement ensues from the perception of declining domestic sales, saturated domestic market, excess capacity, and availability of government incentives. Further, Measson and Campbell-Hunt (2015) illustrate that participation in trade shows fosters networking and entry into global value chains. The remainder of the studies dissect the linkage between barriers and performance.

Barriers consistently distinguish 'high' from 'low' export performance (Dean et al., 2000; Enderwick \& Akoorie, 1994; Gray, 1994; Kahiya \& Dean, 2014). However, there is as much evidence for a directas there is for an inverse relationship. On one hand, trade-related barriers are inversely related to export performance; on the other, financial, market-mix, and resource-related barriers have a positive effect on export performance (Dean et al., 2000; Kahiya \& Dean, 2014).

\subsection{Capabilities and strategy, linkage 3-4}

Eight studies (i.e., Agndal \& Chetty, 2007; Chetty \& Campbell-Hunt, 2003b, 2004; Morrish \& Deacon, 2011; Odlin \& Benson-Rea, 2017; Sedoglavich, 2012; Souchon et al., 2015; Stark et al., 2005) indicate capabilities influence strategy. Capabilities enable facets of entrepreneurial marketing strategy (e.g., proactiveness, innovation-focus, customer intensity, risk management, resource leveraging, and value creation), and rapid growth magnifies the potency of such capabilities (Chetty \& Campbell-Hunt, 2003b; Morrish \& Deacon, 2011; Odlin \& Benson-Rea, 2017). Similarly, Agndal and Chetty (2007) and Souchon et al. (2015) find that market research, information generation, and relationship management empower strategy.

Sedoglavich (2012) adds the notion of strategic fit to the dialogue. She finds a symbiotic connection between technological capabilities and strategy, in that, firms either utilize technology, which fits their internationalization strategy, or adopt an internationalization strategy, which fits pre-existing technology. Likewise, negotiation strategies evolve, depending on whether the INZF is pursuing a hands-off transactional relationship, or an ongoing investment arrangement (Stark et al., 2005). 


\subsection{Capabilities and process, linkage 3-5}

Four studies (i.e., Chetty \& Agndal, 2007; Coviello \& Cox, 2006; Gerschewski et al., 2016; Sedoglavich, 2012) examine the connection between capabilities and process. Chetty and Agndal (2007) suggest networking capabilities enable mode switching during internationalization. Concerning entrepreneurial capabilities, Gerschewski et al. (2016) find evidence for the 'innovative' and 'proactive' dimensions, but not for the 'risk-taking' component. Coviello and Cox (2006) and Sedoglavich (2012) advance the reverse relationship. Coviello and Cox (2006) suggest that network-based internationalization fosters the development of resources and capabilities. Likewise, Sedoglavich (2012) notes licensing, contractual agreements, and joint venturing enhance technological capabilities.

\subsection{Capabilities and outcomes, linkage 3-6}

Eight studies (i.e., Cadogan, Paul, Salminen, Puumalainen, \& Sundqvist, 2001; Chadee \& Mattsson, 1998; Chadee \& Zhang, 2000; Chetty \& Hamilton, 1993; Chung, 2012; McGregor \& Gomes, 1999; Souchon \& Durden, 2003; Thirkell \& Dau, 1998) investigate the relationship between capabilities and outcomes. Historically, INZFs have reported gaps in capabilities especially concerning product development, technology uptake, market research, formal planning, and research and development (McGregor \& Gomes, 1999). Research (e.g., Chadee \& Mattsson, 1998; Chetty \& Hamilton, 1993; Thirkell \& Dau, 1998) shows planning, information, and knowledge-related capabilities have a positive influence on performance.

Strategy mediates, while external factors moderate, the capabilityoutcome relationship (Chadee \& Zhang, 2000; Chung, 2012). For instance export information use mediates the relationship between type of export information and export performance (Souchon \& Durden, 2003). Further, Chadee and Zhang (2000) show that social investment influences 'selling activities' such as business negotiations and problem solution, and these variables, in turn, influence export performance. In a follow-up study, Chung (2012) unpacks the relationships among export market orientation (EMO), responsiveness and strategic performance, and observes a similar pattern of findings. EMO is an international outcome in and of itself. For instance, Cadogan et al. (2001) demonstrate that export coordination and export reward systems exhibit a strong association with EMO behavior.

\subsection{Strategy and outcomes, linkage 4-6}

With 17 studies (e.g., Akoorie \& Enderwick, 1992; Chung, 2012; Chung \& Kuo, 2018; Chung et al., 2012; Dean et al., 2000; Enderwick \& Akoorie, 1994; Gray, 1994; Felzensztein et al., 2014; Hoang, 1998; Morrish \& Deacon, 2011), the strategy-outcome link is the second most frequently researched. The importance of niche strategies is a recurrent theme within this linkage (see Enderwick \& Akoorie, 1994; Morrish \& Deacon, 2011; Odlin \& Benson-Rea, 2017). So fundamental is the selection and targeting of niche markets that it can compensate for the lack of specific marketing acumen (Akoorie \& Enderwick, 1992). Market diversification, product breadth, promotion strategy, intensity of involvement, continuous order flow, proactiveness, and export market responsiveness have a positive effect on export performance (Casey \& Hamilton, 2014; Dean et al., 2000; Gray, 1994; Hoang, 1998; Kahiya \& Dean, 2014). Further, business and political ties moderate this relationship (Chung \& Kuo, 2018).

Corbett (1996) finds that 'global firms' consider quality assurance, worker training and quality function deployment the most important action programs for driving performance, whereas domestic firms view training as the most vital ingredient. Strategy may ensue from interfirm linkages. For example, Felzensztein et al. (2014) elucidate on how inter-firm collaborative marketing initiatives create strategic outcomes embracing customer engagement and retention. Notably, a hostile (as opposed to a benign) external environment amplifies the influence of strategy on performance (Robertson \& Chetty, 2000).

\subsection{Process and outcomes, linkage 5-6}

Eight studies (i.e., Coviello, 2006; Coviello \& Munro, 1997; Gao et al., 2016; Gerschewski \& Xiao, 2015; McNaughton \& Bell, 1999; Pellegrino \& McNaughton, 2015, 2017; Sadeghi et al., 2018) examine the connection between process and outcomes. Gerschewski and Xiao (2015) provide glimpses of performance from the perspective of both conventional enterprises and INVs. Their results highlight that INVs attach more importance to all 12 measures of international performance, compared to non-INVs (i.e., conventional enterprises).

Networks and learning evolve with rapid and early international expansion (Coviello, 2006; Pellegrino \& McNaughton, 2017; Pellegrino \& McNaughton, 2015). At inception, congenital learning is pre-eminent, but as internationalization increases, alternative modes (e.g. experiential and vicarious) emerge (Pellegrino \& McNaughton, 2015; Pellegrino \& McNaughton, 2017). Gao et al. (2016) explore the Ule New Zealand Mall, an online platform selling New Zealand products in China. They note New Zealand Post (NZPOST) provides 'brokered insidership' to New Zealand exporters, reducing uncertainty and cost of experiential learning. While the preceding discussion answered the first research question of how New Zealand firms internationalize, the next section focuses on how the D-SMOPEC model fits in the broader discourse, and what (if anything) distinguishes it from mainstream research.

\section{Discussion and implications for theory and practice}

To underline the implications of this review for theory and practice, this section provides a summary of the model; followed by an assessment of how such internationalization compares to extant literature. The study weaves into the discussion, past reviews conducted on antecedents (i.e., Martineau \& Pastoriza, 2016), capabilities (see İpek, 2018), stimuli (i.e., Leonidou et al., 2007), processes (see Knight \& Liesch, 2016), strategy (i.e., Leonidou, Katsikeas, \& Samiee, 2002), and outcomes (see Sousa, Martínez-López, \& Coelho, 2008); and reviews conducted on the internationalization of firms from specific contexts Africa (i.e., Ibeh et al., 2012), Central and Eastern Europe (see Caputo et al., 2016), China (i.e., Deng, 2012), and United Kingdom (see Wheeler et al., 2008). Finally, the review utilizes reflective remarks by key authors to provide nuance and chart areas of future research.

\subsection{Implications for research}

The principal contribution of research on INZFs, to knowledge, is the depiction of Entrepreneurial Internationalization. In mapping the domain of International Entrepreneurship, Jones et al. (2011) illustrate three clusters - entrepreneurial internationalization, international comparisons of entrepreneurship, and comparative entrepreneurial internationalization. The variables identified and linkages dissected in this review, align with Jones et al.'s (2011) portrayal of entrepreneurial internationalization. The parallels are especially manifest at the first-order (theme) level (p. 637). Thus, the framework provided in this review adds detail and context to Entrepreneurial Internationalization. The salient aspects of the framework are reiterated below.

The model in Fig. 2 offers several possible pathways. Focusing on antecedents, capabilities, processes, and outcomes, an illustrative pathway could be explained as follows; firm-level and managerial antecedents influence capabilities, the international process chosen is subject to the joint influence of antecedents and capabilities, and capabilities and international process influence international outcomes. There are three relationships (i.e., denoted by A, B and C in Fig. 2) where mediation and moderation apply. Of these, only $\mathrm{C}$ (mediation/ moderation between capabilities and international outcomes) has been 
tested. There is an opportunity to identify and test factors which mediate and moderate the link between stimuli and international outcomes. For instance, the review theorizes high entrepreneurial orientation moderates (i.e., strengthens) the relationship between export promotion and export involvement. This connection may hold for other types of stimuli including unsolicited orders or free trade agreements. Another prospect is to test the relationship between international strategy and international process, which has not been subject to empirical scrutiny in this stream of research. To establish the extent to which context matters, the review discusses elements of this framework against the backdrop of extant knowledge and other context-based reviews.

Human capital and managerial socio-cognitive aspects (e.g., age, network base, language skills, international experience, 'immigrant effect', and export commitment) offer informative insights on strategies and outcomes. These elements should be considered the epitome of entrepreneurial internationalization from a D-SMOPEC. They differ from the international expansion of IAFs, ICFs, and ICEEFs whose international activities are closely tied to physical resources (i.e., ICFs), and quality of the institutional environment (i.e., IAFs and ICEEFs) (see Caputo et al., 2016; Deng, 2012; Ibeh et al., 2012).Expansion stimuli (ES) can help distinguish the behavior of INZFs from that of firms from other contexts. For INZFs, internal proactive stimuli (i.e., marketseeking) are the foremost motives underlying internationalization. This differs from extant literature (see Leonidou et al., 2007) which recounts the importance of all major categories of stimuli. For instance, escape logic (i.e., avoiding a hostile domestic market) motivates IAFs, whereas strategic asset- and resource-seeking motives are relevant to the study of ICFs (see Deng, 2012; Ibeh et al., 2012). Thus the internationalization of New Zealand firms is an internally-driven proactive initiative, which embodies entrepreneurial intentionality (Liñán \& Fayolle, 2015).

The capabilities identified in this study (e.g., technology, information generation, export market knowledge/orientation, relationship management, product/service quality, and competitor orientation) are mostly of a threshold or consolidation variety. They denote the bare minimum a venture requires to survive, unlike value-adding and disruptive capabilities, which engender growth. This pattern of findings (i.e., the underrepresentation of dynamic capabilities) is generally consistent with İpek's (2018) review on resources and capabilities.

Unlike extant literature (e.g., Leonidou et al., 2002), which addresses venture-level strategy, research on INZFs underlines the criticality of firm-level strategies (e.g., operational efficiency, cross-cultural negotiation, productivity, sustainability, talent management) to international expansion. Although IAFs and ICFs follow global and regional strategies (Deng, 2012; Ibeh et al., 2012), INZFs combine both approaches as part of strategic portfolio management. The niche strategies are more nuanced than portrayed in extant literature. For instance, large cultural distance implies calibration of promotion, while geographic distance dictates adaptation of distribution.

Concerning international process, the review challenges the popular view (see Knight \& Cavusgil, 1996; Oviatt \& McDougall, 1994) that early-rapid internationalization is the antithesis to incremental internationalization. Research on INZFs portrays these perspectives as complementary paradigms, which encapsulate pivotal decision points in international expansion. The key decision points reflect some measure of effectuation and causation. Further, BGs and INVs are not as prevalent among IAFs and ICEEFs (see Caputo et al., 2016; Ibeh et al., 2012) as there are within the sample of INZFs studied. Indeed, for New Zealand and perhaps other SMOPECs, BGs/INVs are one of the most common forms of internationalizing firms.

Extant literature (e.g., Leonidou et al., 2002; Sousa et al., 2008) notes outcomes are measurable and in most cases performance-related. Operational and strategic outcomes identified in this review include networking, learning, and adoption of export market-oriented behavior. Also of note is the notion of lifestyle entrepreneurship, which challenges assumptions about performance measurement. Measuring the performance of a firm whose mission is to earn a steady-livable income for its owner, should differ from assessing the international performance of a traditional high-growth for-profit internationalizing SME.

To obtain nuance on what differentiates the internationalization of New Zealand firms, the study provides a digest of reflective comments from key authors. Consistent with the proposition in this review, the majority of the authors presumed or hypothesized context was influential, albeit to varying degrees. Professor Sylvie Chetty explains; "Given the above context of the New Zealand business and institutional environment, I did expect that New Zealand SMEs would behave differently".

Emeritus Professor Colin Campbell-Hunt elaborates; "I suspected that strategies would have to differ because of the path dependencies of firms launching from a tiny and isolated economy would equip them with a very distinctive profile of capabilities". Some scholars suggest knowledge on INZFs should be generalizable across certain SMOPECs. Professor David Crick captures this as follows; "Originally, I anticipated that the context potentially adds value to existing knowledge since it involves an open economy that is geographically remote. However, in reality, I found that the institutional context provided certain similarities with other small open economies like Ireland, and Scandinavian countries".

Thus both the results of the synthesis and the illustrative remarks begin to suggest the influence of context is not nearly as sweeping as anticipated. This review concurs with Jurado and Battisti (2019) who argue that while the study of context is fundamental, pinning its influence on business and policy remains nebulous. Professor Rod McNaughton explains; "I think there are nuances of context that could also be teased out, but I don't think many (any?) of the published research that uses a NZ sample does so". It is plausible that the limited influence of context may have resulted from the failure to identify and dissect its effect. Drawing from the content of the review and the reflective comments of authors, the study outlines four areas where researchers could tease out context.

While the dynamics of internationalization may be comparable across SMOPECs a focus on the magnitude of issues faced could be informative. Professor Arthur Grimes clarifies; "we hypothesized that issues would be similar, but of a different scale". The scale and extent of challenges INZFs face may provide nuance on how these differ from other SMOPEC's. For instance, does distance imply high-cost, complexity, uncertainty or limited price competitiveness relative internationalizing firms from other SMOPECs?

Dr. Stephan Gerschewski suggests a focus on international entrepreneurial orientation may help unlock nuance. "The degree of international entrepreneurial orientation of New Zealand SMEs seems to be very high compared to other country contexts, e.g. USA". Future studies could approach this question from three different angles; (a) What underpins the international entrepreneurial orientation of INZFs, (b) How does the international entrepreneurial orientation influence internationalization, and (c) How do the dynamics in (a) and (b) differ from extant knowledge?

Professor David Dean argues "the only empirically documented difference between the organizational behavior of New Zealand organizations and those in other OECD countries is the prominence of 'lifestylers'as leaders of NZ small businesses". Lifestyle entrepreneurship originates from the economic reforms of the 1980's and 1990's which eliminated thousands of jobs. A number of former employees started their own businesses with the goal of earning sufficient money to replace the lost remuneration. A generation removed from this, lifestyle entrepreneurship is still present among New Zealand businesses. What forms of entrepreneurial internationalization does lifestyle entrepreneurship spawn?

According to Professor Rod McNaughton the New Zealand context differs from other OECD countries because of two features - "the absence of large firms" and "low business investment in $R \& D$ ". This possibly creates challenges at two levels; (1) limited opportunities to learn from or benchmark against larger firms, and (2) reduced funding for 
technological innovation. What coping or compensatory strategies do INZFs adopt to surmount these systemic issues? Do INZFs switch to nontechnological innovation to compensate? Addressing these questions is instrumental in developing a nuanced understanding of how context impacts INZFs.

\subsection{Implications for practice}

Although providing a critique of national export strategy (NES) was not the intended goal of this review, the macro-level outcomes of internationalization outlined in the conceptual model underscore the relevance of this research for policymaking. Policymakers have made progress toward accomplishing some of the initiatives underpinning the trade strategy. For instance, an updated customs regime with a single trade window for streamlining customs/international logistics activities has been rolled out, and New Zealand has since acceded to the Global Procurement Agreement. Nonetheless, the efficacy of some of these initiatives is still open to debate. For example, although policymakers aim to secure FTAs to cover $95 \%$ of all merchandise exports by 2030 , the handful studies exploring the link between FTAs and market access/ selection have reported mixed results. Yet, trade data do appear to back the importance of market access. Post-FTAs exports to China and several markets in Southeast Asia, have risen substantially. China is now New Zealand's number one export destination by value, and exports to each of the following markets - Indonesia, Singapore, and Thailand now exceed $\$ 1$ billion (Statistics New Zealand, 2018). One interpretation is that INZFs may be targeting opportunities created by FTAs, while a skeptical view argues exports to these regions were poised to grow organically (i.e., in line with economic growth) and not necessarily in response to FTAs. This review welcomes econometric modelling and shift share analysis of export patterns to help disentangle these effects.

\subsection{Limitations and Concluding Remarks}

The structured and systematic search procedure followed, does not preclude the existence of additional studies, which could have qualified for the review. The decision to exclude other types of publications (e.g., regional journals, books and book chapters), although justifiable in light of creating an equitable basis for comparison, may have led to the omission of potentially relevant research. Coding and synthesis followed a rudimentary procedure aimed at identifying the pattern of linkages between the variables. Nonetheless, the contribution of this review is worth reiterating.

The study cast internationalization from a distant small open economy (D-SMOPEC) as a unique case which could facilitate the falsification of theory. To test the proposition, the study offered a systematic review on the internationalization of New Zealand firms, a comparison of the knowledge content to mainstream research, and a nuanced interpretation of findings based on reflective comments of key authors. Contrary to the proposition, there is limited evidence to suggest the internationalization of New Zealand firms differs from mainstream knowledge. Whereas proponents of 'context in IB' (e.g., Michailova, 2011; Poulis et al., 2013; Schotter et al., 2018; Teagarden et al., 2018; Tsui, 2007; Welch et al., 2011) would predict uniqueness of context leads to 'falsification' of theory, the model presented in this review, which generally mirrors mainstream research (e.g., Kuivalainen, Sundqvist, Saarenketo, \& McNaughton, 2012, p. 452), has unexpectedly led to the 'verification' or substantiation of extant knowledge. Thus country specific configurations and attributes of New Zealand appear to exert limited influence on INZFs. It is important to note, however, that INZFs differ from other unique contexts - internationalizing African firms (IAFs), internationalizing Chinese firms (ICFs), and internationalizing Central and Eastern European firms (ICEEFs). Distinguishing elements include for instance, escape logic as motivation for internationalization (see IAFs), presence of higher modes of market entry (see ICFs) and low prevalence of BGs/INVs (i.e.,
ICEEFs)

Failure of a distant-SMOPEC, which researchers term 'a naturally occurring laboratory', to definitively capture the importance of national context in IB raises two questions. Does the global business context, which is similar for all firms, supplant the domestic market context? Alternatively, could it be that researchers have fallen somewhat short of teasing out nuance surrounding context? This latter question has provided the platform for future research outlined above. It also opens more debate on context in IB.

\section{Acknowledgements}

I'm thankful to the following scholars for their insightful reflective comments on the internationalization of New Zealand firms.

Professor Martina Battisti

University of Portsmouth, United Kingdom.

Emeritus Professor Colin Campbell-Hunt.

University of Otago, New Zealand.

Professor Sylvie Chetty

Uppsala University, Sweden.

Professor Nicole Coviello.

Wilfrid Laurier University, Canada.

Professor David Crick

University of Ottawa, Canada.

Associate Professor David Dean.

Lincoln University, New Zealand.

Professor Peter Enderwick

Auckland University of Technology, New Zealand.

Dr Stephan Gerschewski

University of Kent, United Kingdom.

Professor Arthur Grimes

Motu and Victoria University of Wellington, New Zealand.

Emeritus Professor Bob Hamilton

University of Canterbury, New Zealand.

Professor Rod McNaughton

University of Auckland, New Zealand.

Associate Professor Sussie Morrish

University of Canterbury, New Zealand.

Dr Paresha Sinha

University of Waikato, New Zealand.

\section{Appendix A. Supplementary data}

Supplementary material related to this article can be found, in the online version, at doi:https://doi.org/10.1016/j.ibusrev.2019.101621.

\section{References}

Adler, P. S., \& Kwon, S. W. (2002). Social capital: Prospects for a new concept. Academy of Management Review, 27(1), 17-40.

Agndal, H., \& Chetty, S. (2007). The impact of relationships on changes in internationalization strategies of SMEs. European Journal of Marketing, 41(11/12), 1449-1474.

Akoorie, M. (1993). Patterns of foreign direct investment by large New Zealand firms. International Business Review, 2(2), 169-189.

Akoorie, M., \& Enderwick, P. (1992). The international operations of New Zealand companies. Asia Pacific Journal of Management, 9(1), 51-69.

Akoorie, M., Barber, K., \& Enderwick, P. (1993). Europe 1992: Implications for New Zealand business. European Journal of Marketing, 27(1), 22-34.

Alon, I., Dana, L. P., \& Jenkins, A. (2009). International business by SMEs: Empirical findings from New Zealand. Journal of International Business and Economy, 10(2), 59-78.

Andersen, O. (1993). On the internationalization process of firms: A critical analysis. Journal of International Business Studies, 24(2), 209-231.

Au, A. K. M., \& Enderwick, P. (1994). Small firms in international joint ventures in China: The New Zealand experience. Journal of Small Business Management, 32(2), 88-94.

Baker, G. (2009). Ready ... set ... GLOBAL!. New Zealand Business, 23(11), 16-17.

Barney, J. B. (2001). Resource-based theories of competitive advantage: A ten-year retrospective on the resource-based view. Journal of Management, 27(6), 643-650.

Battisti, M., \& Perry, M. (2008). Creating opportunity for small-firm exporters through regional free trade agreements: A strategic perspective from New Zealand. 
Australasian Journal of Regional Studies, 14(3), 275-285.

Battisti, M., Jurado, T., \& Perry, M. (2014). Understanding small-firm reactions to free trade agreements: Qualitative evidence from New Zealand. Journal of Small Business and Enterprise Development, 21(2), 327-344.

Baxter, P., \& Jack, S. (2008). Qualitative case study methodology: Study design and implementation for novice researchers. The Qualitative Report, 13(4), 544-559.

Bell, J. (1995). The internationalization of small computer software firms: A further challenge to "stage" theories. European Journal of Marketing, 29(8), 60-75.

Bell, J., McNaughton, R., \& Young, S. (2001). "Born-again global" firms: An extension to the "born global" phenomenon. Journal of International Management, 7(3), 173-189.

Bilkey, W. J. (1978). An attempted integration of the literature on the export behavior of firms. Journal of International Business Studies, 9(1), 33-46.

Bilkey, W. J., \& Tesar, G. (1977). The export behavior of smaller-sized Wisconsin manufacturing firms. Journal of International Business Studies, 8(1), 93-98.

Brownie, S., \& Dalziel, P. (1993). Shift-share analyses of New Zealand exports, 1970-1984. New Zealand Economic Papers, 27(2), 233-249.

Cadogan, J., Paul, N., Salminen, R., Puumalainen, K., \& Sundqvist, S. (2001). Key antecedents to export market-oriented behaviors: A cross-national empirical examination. International Journal of Research in Marketing, 18(3), 261-282.

Canabal, A., \& White, G. O., III (2008). Entry mode research: Past and future. International Business Review, 17(3), 267-284.

Caputo, A., Pellegrini, M., Dabic, M., \& Dana, L. P. (2016). Internationalization of firms from Central and Eastern Europe: A systematic literature review. European Business Review, 28(6), 630-651.

Casey, S., \& Hamilton, R. (2014). Export performance of small firms from small countries: The case of New Zealand. Journal of International Entrepreneurship, 12(3), 254-269.

Caughey, M., \& Chetty, S. (1994). Pre-export behavior of small manufacturing firms in New Zealand. International Small Business Journal, 12(3), 62-68.

Chabowski, B., Kekec, P., Morgan, N. A., Hult, G. T. M., Walkowiak, T., \& Runnalls, B. (2018). An assessment of the exporting literature: Using theory and data to identify future research directions. Journal of International Marketing, 26(1), 118-143.

Chadee, D. (2004). Foreign environmental impacts on export performance: A study of agribusiness firms exporting to Japan. Journal of International Food \& Agribusiness Marketing, 14(4), 5-27.

Chadee, D., \& Mattsson, J. (1998). Do service and merchandise exporters behave and perform differently? A New Zealand investigation. European Journal of Marketing, 32(9/10), 830-842.

Chadee, D., \& Zhang, B. (2000). The impact of Guanxi on export performance: A study of New Zealand firms exporting to China. Journal of Global Marketing, 14(1-2), 129-149.

Chetty, S. (1999). Dimensions of internationalization of manufacturing firms in the apparel industry. European Journal of Marketing, 33(1/2), 121-142.

Chetty, S., \& Agndal, H. (2007). Social capital and its influence on changes in internationalization mode among small and medium-sized enterprises. Journal of International Marketing, 15(1), 1-29.

Chetty, S., \& Campbell-Hunt, C. (2003a). Paths to internationalization among small-to medium-sized firms: A global versus regional approach. European Journal of Marketing, 37(5/6), 796-820.

Chetty, S., \& Campbell-Hunt, C. (2003b). Explosive international growth and problems of success amongst small to medium-sized firms. International Small Business Journal, 21(1), 5-27.

Chetty, S., \& Campbell-Hunt, C. (2004). A strategic approach to internationalization: A traditional versus a "born-global" approach. Journal of International Marketing, 12(1), $57-81$.

Chetty, S., \& Hamilton, R. (1993). The export performance of smaller firms: A multi-case study approach. Journal of Strategic Marketing, 1(4), 247-256.

Chetty, S., \& Hamilton, R. (1996). The process of exporting in owner-controlled firms. International Small Business Journal, 14(2), 12-25.

Chetty, S., \& Holm, D. (2000). Internationalization of small to medium-sized manufacturing firms: A network approach. International Business Review, 9(1), 77-93.

Chetty, S., \& Patterson, A. (2002). Developing internationalization capability through industry groups: The experience of a telecommunications joint action group. Journal of Strategic Marketing, 10(1), 69-89.

Chetty, S., \& Stangl, L. (2010). Internationalization and innovation in a network relationship context. European Journal of Marketing, 44(11/12), 1725-1743.

Chetty, S., \& Wilson, H. (2003). Collaborating with competitors to acquire resources. International Business Review, 12(1), 61-81.

Chetty, S., Ojala, A., \& Leppäaho, T. (2015). Effectuation and foreign market entry of entrepreneurial firms. European Journal of Marketing, 49(9/10), 1436-1459.

Chung, H. (2002). Determination of export channel strategies: The experience of New Zealand firms. Journal of Asia-Pacific Business, 3(3), 25-52.

Chung, H. (2003). International standardization strategies: The experiences of Australian and New Zealand firms operating in the greater China markets. Journal of International Marketing, 11(3), 48-82.

Chung, H. F. (2007). International marketing standardization strategies analysis: A crossnational investigation. Asia Pacific Journal of Marketing and Logistics, 19(2), 145-167.

Chung, H. F. (2009). Structure of marketing decision making and international marketing standardization strategies. European Journal of Marketing, 43(5/6), 794-825.

Chung, H. (2012). Export market orientation, managerial ties, and performance. International Marketing Review, 29(4), 403-423.

Chung, H., \& Enderwick, P. (2001). An investigation of market entry strategy selection: Exporting vs foreign direct investment modes-a home-host country scenario. Asic Pacific Journal of Management, 18(4), 443-460.

Chung, H. F., \& Kuo, T. (2018). When and how managerial ties matter in international competitive strategy, export financial and strategic performance framework: A standardized or customized approach? European Journal of Marketing, 52(1/2), $260-278$
Chung, H., \& Tung, R. (2013). Immigrant social networks and foreign entry: Australia and New Zealand firms in the European Union and Greater China. International Business Review, 22(1), 18-31.

Chung, H. F., Lu Wang, C., \& Huang, P. H. (2012). A contingency approach to international marketing strategy and decision-making structure among exporting firms. International Marketing Review, 29(1), 54-87.

Corbett, L. (1996). A comparative study of the operations strategies of globally-and domestically-oriented New Zealand manufacturing firms. International Journal of Production Research, 34(10), 2677-2689.

Correia, I., Neves, J. C., \& Rebelo, S. (1995). Business cycles in a small open economy. European Economic Review, 39(6), 1089-1113.

Coviello, N. (2006). The network dynamics of international new ventures. Journal of International Business Studies, 37(5), 713-731.

Coviello, N., \& Cox, M. (2006). The resource dynamics of international new venture networks. Journal of International Entrepreneurship, 4(2), 113-132.

Coviello, N. E., \& Jones, M. V. (2004). Methodological issues in international entrepreneurship research. Journal of Business Venturing, 19(4), 485-508.

Coviello, N., \& Martin, K. (1999). Internationalization of service SMEs: An integrated perspective from the engineering consulting sector. Journal of International Marketing, 7(4), 42-66.

Coviello, N., \& Munro, H. (1995). Growing the entrepreneurial firm: Networking for international market development. European Journal of Marketing, 29(7), 49-61.

Coviello, N., \& Munro, H. (1997). Network relationships and the internationalization process of small software firms. International Business Review, 6(4), 361-386.

Crick, D., \& Crick, J. (2015). Learning and decision making in marketing planning: A study of New Zealand vineyards. Marketing Intelligence and Planning, 33(5), 707-732.

Crick, D., \& Lindsay, V. (2015). Service and service-intensive New Zealand internationalizing SMEs: Managers' perceptions of government assistance. Marketing Intelligence and Planning, 33(3), 366-393.

Czinkota, M. R., \& Johnston, W. J. (1981). Segmenting US firms for export development. Journal of Business Research, 9(4), 353-365.

Dana, L. P. (2003). The challenge of exporting fresh food from the Chatham Islands to markets overseas. British Food Journal, 105(1/2), 9-22.

Dana, L. P., Chan, T., \& Chia, D. (2008). Micro-enterprise internationalization without support: The case of Angus exports. The International Journal of Entrepreneurship and Innovation, 9(1), 5-10.

Da Rocha, A., \& Christensen, C. (1994). The export experience of a developing country: A review of empirical studies of export behavior and the performance of Brazilian firms. Advances in International Marketing, 6, 111-142 JAI Greenwich.

Dean, D., Gan, C., \& Myers (1998). An investigation of the relationship between a firm's perceived export barriers and stages of export development: An analysis of Canterbury manufacturing firms. Journal of Enterprising Culture, 6(2), 199-216.

Dean, D., Mengüç, B., \& Myers, C. (2000). Revisiting firm characteristics, strategy, and export performance relationship: A survey of the literature and an investigation of New Zealand small manufacturing firms. Industrial Marketing Management, 29(5), 461-477.

De Clercq, D., Sapienza, H. J., Yavuz, R. I., \& Zhou, L. (2012). Learning and knowledge in early internationalization research: Past accomplishments and future directions. Journal of Business Venturing, 27(1), 143-165.

Deng, P. (2012). The internationalization of Chinese firms: A critical review and future research. International Journal of Management Reviews, 14(4), 408-427.

Deng, S., Duffy, M., \& Harrison, G. (1995). Internationalization in small, commodity based economies: The New Zealand example. Asia Pacific Journal of Marketing and Logistics, 7(1/2), 37-61.

Dhanaraj, C., \& Beamish, P. W. (2003). A resource-based approach to the study of export performance. Journal of Small Business Management, 41(3), 242-261.

Dunning, J. H. (1993). Multinational enterprises and the global economy. Harlow: AddisonWesley.

Edmondson, A. C., \& McManus, S. E. (2007). Methodological fit in management field research. Academy of Management Review, 32(4), 1246-1264.

Enderwick, P., \& Akoorie, M. (1994). Pilot study research note: The employment of foreign language specialists and export success-The case of New Zealand. International Marketing Review, 11(4), 4-18.

Enderwick, P., \& Hodgson, D. (1993). Expatriate management practices of New Zealand business. International Journal of Human Resource Management, 4(2), 407-423.

Enderwick, P., \& Ronayne, E. (2004). Reconciling entrepreneurship and organizational structure in international operations: Evidence from New Zealand specialist food exporters. Journal of Asia Pacific Marketing, 3(2), 53-68.

Endo, T., Delbridge, K., \& Morris, J. (2015). Does Japan still matter? Past tendencies and future opportunities in the study of Japanese firms. International Journal of Management Reviews, 17(1), 101-123.

Eisenhardt, K. M., \& Graebner, M. E. (2007). Theory building from cases: Opportunities and challenges. Academy of Management Journal, 50(1), 25-32.

Evers, N., \& Knight, J. (2008). Role of international trade shows in small firm inter nationalization: A network perspective. International Marketing Review, 25(5), 544-562.

Fabling, R., \& Sanderson, L. (2013). Exporting and firm performance: Market entry, investment and expansion. Journal of International Economics, 89(2), 422-431.

Fabling, R., Grimes, A., \& Sanderson, L. (2012). Whatever next? Export market choices of New Zealand firms. Papers in Regional Science, 91(1), 137-159.

Felzensztein, C., Stringer, C., Benson-Rea, M., \& Freeman, S. (2014). International marketing strategies in industrial clusters: Insights from the Southern Hemisphere. Journal of Business Research, 67(5), 837-846.

Fletcher, M., Zhao, Y., Plakoyiannaki, E., \& Buck, T. (2018). Three pathways to case selection in international business: A twenty-Year review, analysis and synthesis. International Business Review, 27(4), 755-766. 
Flyvbjerg, B. (2006). Five misunderstandings about case-study research. Qualitative Inquiry, 12(2), 219-245.

Frederick, H., \& Monsen, E. (2011). New Zealand's perfect storm of entrepreneurship and economic development. Small Business Economics, 37(2), 187-204.

Freeman, S., Edwards, R., \& Schroder, B. (2006). How smaller born-global firms use networks and alliances to overcome constraints to rapid internationalization. Journal of international Marketing, 14(3), 33-63.

Gao, H., Ren, M., Zhang, J., \& Sun, R. (2016). Network gatekeeping in SME exporters' market entry in China. International Marketing Review, 33(2), 276-297.

Gerschewski, S., Lew, Y. K., Khan, Z., \& Park, B. I. (2018). Post-entry performance of international new ventures: The mediating role of learning orientation. International Small Business Journal, 36(7), 807-828.

Gerschewski, S., \& Xiao, S. (2015). Beyond financial indicators: An assessment of the measurement of performance for international new ventures. International Business Review, 24(4), 615-629.

Gerschewski, S., Lindsay, V., \& Rose, E. (2016). Advancing the entrepreneurial orientation construct: The role of passion and perseverance. Review of International Business and Strategy, 26(4), 446-471.

Gerschewski, S., Rose, E., \& Lindsay, V. (2015). Understanding the drivers of international performance for born global firms: An integrated perspective. Journal of World Business, 50(3), 558-575.

Ghauri, P., Lutz, C., \& Tesfom, G. (2003). Using networks to solve export-marketing problems of small-and medium-sized firms from developing countries. European Journal of Marketing, 37(5/6), 728-752.

Gray, B. (1994). Active and passive international marketing strategies: The case of two state-owned broadcasters. European Journal of Marketing, 28(2), 42-56.

Gray, B. (1997). Profiling managers to improve export promotion targeting. Journal of International Business Studies, 28(2), 387-420.

Greenhalgh, T., Robert, G., Macfarlane, F., Bate, P., Kyriakidou, O., \& Peacock, R. (2005). Storylines of research in diffusion of innovation: A meta-narrative approach to systematic reviews. Social Science and Medicine, 61, 417-430.

Hamilton, R., \& Dana, L. P. (2003). An increasing role for small business in New Zealand. Journal of Small Business Management, 41(4), 402-408.

Hielkema, H., \& Hongisto, P. (2013). Developing the Helsinki smart city: The role of competitions for open data applications. Journal of the Knowledge Economy, 4(2), 190-204.

Hoang, P. (1998). A causal study of relationships between firm characteristics, international marketing strategies, and export performance. Management International Review, 38(1), 73-93.

Ibeh, K., Wilson, J., \& Chizema, A. (2012). The internationalization of African firms 1995-2011: Review and implications. Thunderbird International Business Review, 54(4), 411-427.

Ipek, I. (2018). The Resource-Based View within the export context: An integrative review of empirical studies. Journal of Global Marketing, 31(3), 157-179.

İpek, I. (2019). Organizational learning in exporting: A bibliometric analysis and critical review of the empirical research. International Business Review, 28(3), 544-559. https://doi.org/10.1016/j.ibusrev.2018.11.010.

Jackson, G., \& Deeg, R. (2008). Comparing capitalisms: Understanding institutional diversity and its implications for international business. Journal of International Business Studies, 39, 540-561.

Jin, H., \& Hurd, F. (2018). Exploring the impact of digital platforms on SME internationalization: New Zealand SMEs use of the Alibaba platform for Chinese marke entry. Journal of Asia-Pacific Business, 19(2), 72-95.

Johanson, J., \& Mattsson, L. G. (2015). Internationalization in industrial systems - A network approach. In M. Forsgren, U. Holm, \& J. Johanson (Eds.). Knowledge, networks and power. London: Palgrave Macmillan.

Johanson, J., \& Wiedersheim-Paul, F. (1975). The internationalization of the firm-four Swedish cases 1. Journal of management studies, 12(3), 305-323.

Johanson, J., \& Vahlne, J.-E. (1977). The internationalization process of the firm: A model of knowledge development and increasing foreign market commitments. Journal of International Business Studies, 8(1), 23-32.

Jones, M., Coviello, N., \& Tang, Y. K. (2011). International entrepreneurship research (1989-2009): A domain ontology and thematic analysis. Journal of Business Venturing, 26(6), 632-659.

Jones, O., \& Gatrell, C. (2014). The future of writing and reviewing for IJMR. International Journal of Management Reviews, 16(3), 249-264.

Jurado, T., \& Battisti, M. (2019). The evolution of SME policy: The case of New Zealand. Regional Studies, Regional Science, 6(1), 32-54.

Kahiya, E. T. (2018). Five decades of research on export barriers: Review and future directions. International Business Review, 27(6), 1172-1188.

Kahiya, E. T. (2017). Export barriers as liabilities: Near perfect substitutes. European Business Review, 29(1), 61-102.

Kahiya, E. T. (2013). Export barriers and path to internationalization: A comparison of conventional enterprises and international new ventures. Journal of International Entrepreneurship, 11(1), 3-29.

Kahiya, E. T., \& Dean, D. (2014). Export performance: Multiple predictors and multiple measures approach. Asia Pacific Journal of Marketing and Logistics, 26(3), 378-407.

Kahiya, E. T., \& Dean, D. (2015). Export barriers and business confidence: A quasi longitudinal examination. Asia Pacific Journal of Marketing and Logistics, 27(2), 294-323.

Kahiya, E. T., \& Dean, D. (2016). Export stages and export barriers: Revisiting traditional export development. Thunderbird International Business Review, 58(1), 75-89.

Kahiya, E. T., Dean, D., \& Heyl, J. (2014). Export barriers in a changing institutional environment: A quasi-longitudinal study of New Zealand's manufacturing exporters. Journal of International Entrepreneurship, 12(4), 331-364.

Kraaijenbrink, J., Spender, J.-C., \& Groen, A. J. (2010). The Resource-Based View: A review and assessment of its critiques. Journal of Management, 36(1), 349-372. https://doi.org/10.1177/0149206309350775.

Keupp, M. M., \& Gassmann, O. (2009). The past and the future of international entrepreneurship: A review and suggestions for developing the field. Journal of Management, 35(3), 600-633.

Knight, G. A., \& Cavusgil, S. T. (1996). Advances in International Marketing. In S. T. Cavusgil, \& T. Madsen (Vol. Eds.), The Born Global Firm: A Challenge to Traditional Internationalization Theory: 8, (pp. 11-26). Greenwich, CT: JAI Press.

Knight, G., \& Liesch, P. (2016). Internationalization: From incremental to born global. Journal of World Business, 51(1), 93-102.

Kuivalainen, O., Sundqvist, S., Saarenketo, S., \& McNaughton, R. (2012). Guest EditorialInternationalization patterns of small and medium size enterprises. International Marketing Review, 29(5), 448-465.

Le Heron, R. (1980). Exports and linkage development in manufacturing firms: The example of export promotion in New Zealand. Economic Geography, 56(4), 281-299.

Leppäaho, T., Chetty, S., \& Dimitratos, P. (2018). Network embeddedness in the internationalization of biotechnology entrepreneurs. Entrepreneurship \& Regional Development, 30(5-6), 562-584.

Leonidou, L., \& Katsikeas, C. (2010). Integrative assessment of exporting research articles in business journals during the period 1960-2007. Journal of Business Research, 63(8), 879-887.

Leonidou, L., Katsikeas, C., \& Coudounaris, D. (2010). Five decades of business research into exporting: A bibliographic analysis. Journal of International Management, 16(1), 78-91.

Leonidou, L., Katsikeas, C., \& Samiee, S. (2002). Marketing strategy determinants of export performance: A meta-analysis. Journal of Business Research, 55(1), 51-67.

Leonidou, L., Katsikeas, C., Palihawadana, D., \& Stavroula Spyropoulou, S. (2007). An analytical review of the factors stimulating smaller firms to export: Implications for policy-makers. International Marketing Review, 24(6), 735-770.

Levitt, B., \& March, J. G. (1988). Organizational learning. Annual Review of sociology, 14(1), 319-338.

Li, M., He, X., \& Sousa, C. M. (2017). A review of the empirical research on export channel selection between 1979 and 2015. International Business Review, 26(2), 303-323.

Liñán, F., \& Fayolle, A. (2015). A systematic literature review on entrepreneurial intentions: Citation, thematic analyses, and research agenda. International Entrepreneurship and Management Journal, 11(4), 907-933.

Linstone, H. A., \& Turoff, M. (1975). The Delphi method. Reading, MA: AddisonWesley3-12.

Loane, S., Bell, J., \& McNaughton, R. (2007). A cross-national study on the impact of management teams on the rapid internationalization of small firms. Journal of World Business, 42(4), 489-504.

Manolova, T. S., Manev, I. M., \& Gyoshev, B. S. (2010). In good company: The role of personal and inter-firm networks for new-venture internationalization in a transition economy. Journal of World Business, 45(3), 257-265.

Marcotte, C. (2013). Measuring entrepreneurship at the country level: A review and research agenda. Entrepreneurship and Regional Development, 25(3-4), 174-194.

Martineau, C., \& Pastoriza, D. (2016). International involvement of established SMEs: A systematic review of antecedents, outcomes and moderators. International Business Review, 25(2), 458-470.

McGregor, J., \& Gomes, C. (1999). Technology uptake in small and medium-sized enterprises: Some evidence from New Zealand. Journal of Small Business Management 37(3), 94-102.

McNaughton, R., \& Bell, J. (1999). Brokering networks of small firms to generate social capital for growth and internationalization. In A. M. Rugman, \& R. W. Wright (Eds.) Research in global strategic management. International entrepreneurship: Globalization of emerging businesses. Stamford: JAI Press.

Measson, N., \& Campbell-Hunt, C. (2015). How SMEs use trade shows to enter global value chains. Journal of Small Business and Enterprise Development, 22(1), 99-126.

Mehrtens, J., Cragg, P. B., \& Mills, A. M. (2001). A model of Internet adoption by SMEs. Information \& Management, 39(3), 165-176.

Melin, L. (1992). Internationalization as a strategy process. Strategic Management Journal, 13(2), 99-118.

Mendoza, E. G. (1991). Real business cycles in a small open economy. The American Economic Review, 797-818.

Michailova, S. (2011). Contextualizing in international business research: Why do we need more of it and how can we be better at it? Scandinavian Journal of Management, 27(1), 129-139.

Ministry of Business Innovation and Employment (2017). Small business factsheet. https:// www.mbie.govt.nz/assets/30e852cf56/small-business-factsheet-2017.pdf.

Morris, M. H., Schindehutte, M., \& LaForge, R. W. (2002). Entrepreneurial marketing: A construct for integrating emerging entrepreneurship and marketing perspectives. Journal of Marketing Theory and Practice, 10(4), 1-19.

Morrish, S., \& Deacon, J. (2011). A tale of two spirits: Entrepreneurial marketing at 42Below vodka and Penderyn whisky. Journal of Small Business and Entrepreneurship, 24(1), 113-124.

New Zealand Government (2017). PM launches ambitious trade agenda. Press release - 24 March 2017. https://www.beehive.govt.nz/release/pm-launches-ambitious-tradeagenda.

New Zealand Institute of Economics Research (2009). NZ exports - more diverse than commonly thought. https://treasury.govt.nz/sites/default/files/2017-11/tfr-nze20oct09.pdf.

New Zealand Treasury (2014). Holding on and letting go: Opportunities and challenges for NZ's economic performance: A perspective from the Treasury. https://treasury.govt.nz/ sites/default/files/2018-02/holg14.pdf.

Odlin, D., \& Benson-Rea, M. (2017). Competing on the edge: Implications of network position for internationalizing small-and medium-sized enterprises. International 
Business Review, 26(4), 736-748.

Osborne, K. (1996). The channel integration decision for small-to medium-sized manufacturing exporters. International Small Business Journal, 14(3), 40-56.

Oviatt, B. M., \& McDougall, P. P. (1994). Toward a theory of international new ventures. Journal of International Business Studies, 25(1), 45-64.

Park, S., LiPuma, J., \& Prange, C. (2015). Venture capitalist and entrepreneur knowledge of new venture internationalization: A review of knowledge components. International Small Business Journal, 33(8), 901-928.

Paul, J., \& Rosado-Serrano, A. (2019). Gradual internationalization vs. born-global/international new venture models: A review and research agenda. International Marketing Review, 36(6), 830-858. https://doi.org/10.1108/IMR-10-2018-0280.

Pawson, R., Greenhalgh, T., Harvey, G., \& Walshe, K. (2005). Realist review-a new method of systematic review designed for complex policy interventions. Journal of Health Services Research and Policy, 10(1), 21-34.

Pellegrino, J., \& McNaughton, R. (2015). The co-evolution of learning and internationalization strategy in international new ventures. Management International Review, 55(4), 457-483.

Pellegrino, J., \& McNaughton, R. (2017). Beyond learning by experience: The use of al ternative learning processes by incrementally and rapidly internationalizing SMEs. International Business Review, 26(4), 614-627.

Poulis, K., Poulis, E., \& Plakoyiannaki, E. (2013). The role of context in case study selection: An international business perspective. International Business Review, 22(1), 304-314.

Prange, C., \& Verdier, S. (2011). Dynamic capabilities, internationalization processes and performance. Journal of World Business, 46(1), 126-133.

Rennie, M. W. (1993). Born global. The McKinsey Quarterly, (4), 45-53.

Reynolds, N. L., Simintiras, A. C., \& Diamantopoulos, A. (2003). Theoretical justification of sampling choices in international marketing research: Key issues and guidelines for researchers. Journal of International Business Studies, 34(1), 80-89.

Ribau, C., Moreira, A., \& Raposo, M. (2018). SME internationalization research: Mapping the state of the art. Canadian Journal of Administrative Sciences, 35(2), 280-303.

Robertson, C., \& Chetty, S. (2000). A contingency-based approach to understanding export performance. International Business Review, 9(2), 211-235.

Sadeghi, A., Rose, E. L., \& Chetty, S. (2018). Disentangling the effects of post-entry speed of internationalization on export performance of INVs. International Small Business Journal, 36(7), 780-806.

Salipante, P., Notz, W., \& Bigelow, J. (1982). A matrix approach to literature reviews. Research in organizational behavior, 4, Greenwich, CT: JAI Press321-348.

Sapienza, H. J., Autio, E., George, G., \& Zahra, S. A. (2006). A capabilities perspective on the effects of early internationalization on firm survival and growth. Academy of Management Review, 31(4), 914-933.

Sarasvathy, S. D. (2001). Causation and effectuation: Toward a theoretical shift from economic inevitability to entrepreneurial contingency. Academy of Management Review, 26(2), 243-263.

Sedoglavich, V. (2012). Technological imperatives in the internationalization process: Results from a qualitative investigation of high-tech SMEs. Management Research Review, 35(5), 441-459.

Sharma, D. D., \& Blomstermo, A. (2003). The internationalization process of born globals: A network view. International Business Review, 12(6), 739-753.

Shaw, V., \& Darroch, J. (2004). Barriers to internationalization: A study of entrepreneurial new ventures in New Zealand. Journal of International Entrepreneurship, 2(4), 327-343.

Siggelkow, N. (2007). Persuasion with case studies. Academy of Management Journal, 50(1), 20-24.

Sinha, P., \& Akoorie, M. (2010). Sustainable environmental practices in the New Zealand wine industry: An analysis of perceived institutional pressures and the role of exports. Journal of Asia-Pacific Business, 11(1), 50-74.

Sinha, P., Wang, M., Scott-Kennel, J., \& Gibb, J. (2015). Paradoxes of psychic distance and market entry by software INVs. European Business Review, 27(1), 34-59.

Souchon, A., \& Durden, G. (2003). Making the most out of export information: An exploratory study of UK and New Zealand exporters. Journal of Euromarketing, 11(4), $65-86$.

Souchon, A., Dewsnap, B., Durden, G., Axinn, C., \& Holzmüller, H. (2015). Antecedents to export information generation: A cross-national study. International Marketing Review, 32(6), 732-761.

Sousa, C., Martínez-López, F., \& Coelho, F. (2008). The determinants of export performance: A review of the research in the literature between 1998 and 2005". International Journal of Management Reviews, 10(4), 343-374.

Schotter, A. P., Buchel, O., \& Vashchilko, T. (2018). Interactive visualization for research contextualization in international business. Journal of World Business, 53(3), 356-372.

Stake, R. E. (1995). The art of case study research. Thousand Oaks, CA: Sage.

Stark, A., Fam, K., Waller, D., \& Tian, Z. (2005). Chinese negotiation practice: A perspective from New Zealand exporters. Cross Cultural Management: An International Journal, 12(3), 85-102.

Statistics New Zealand (2018). Goods and services trade by country: Year ended March 2018. https://www.stats.govt.nz/information-releases/goods-and-services-trade-bycountry-year-ended-march-2018.

Statistics New Zealand (2016). 2015 New Zealand Business Operations Survey. http:// archive.stats.govt.nz/browse for stats/businesses/business growth and innovation/ BusinessOperationsSurvey_HOTP2015.aspx.

Sternad, D., Jaeger, S., \& Staubmann, C. (2013). Dynamic capabilities of resource-poor exporters: A study of SMEs in New Zealand. Small Enterprise Research, 20(1), 2-20.

Tallman, S., \& Fladmoe-Lindquist, K. (2002). Internationalization, globalization, and capability-based strategy. California Management Review, 45(1), 116-135.

Teagarden, M. B., Von Glinow, M. A., \& Mellahi, K. (2018). Contextualizing international business research: Enhancing rigor and relevance. Journal of World Business, 53(3), 303-306.

Thirkell, P., \& Dau, R. (1998). Export performance: Success determinants for New Zealand manufacturing exporters. European Journal of Marketing, 32(9/10), 813-829.

Torraco, R. (2005). Writing integrative literature reviews: Guidelines and examples. Human Resource Development Review, 4(3), 356-367.

Tranfield, D., Denyer, D., \& Smart, P. (2003). Towards a methodology for developing evidence-informed management knowledge by means of systematic review. British Journal of Management, 14(3), 207-222.

Tsui, A. S. (2007). From homogenization to pluralism: International management research in the academy and beyond. Academy of Management Journal, 50(6), 1353-1364.

Uner, M. M., Kocak, A., Cavusgil, E., \& Cavusgil, S. T. (2013). Do barriers to export vary for born globals and across stages of internationalization? An empirical inquiry in the emerging market of Turkey. International Business Review, 22(5), 800-813.

Vasilchenko, E., \& Morrish, S. (2011). The role of entrepreneurial networks in the exploration and exploitation of internationalization opportunities by information and communication technology firms. Journal of International Marketing, 19(4), 88-105.

Webster, J., \& Watson, R. (2002). Analyzing the past to prepare for the future: Writing a literature review. MIS Quarterly, 26, 13-23.

Welch, C., \& Paavilainen-Mäntymäki, E. (2014). Putting process (back) in: Research on the internationalization process of the firm. International Journal of Management Reviews, 16(1), 2-23.

Welch, C., Piekkari, R., Plakoyiannaki, E., \& Paavilainen-Mäntymäki, E. (2011) Theorizing from case studies: Towards a pluralist future for international business research. Journal of International Business Studies, 42(5), 740-762.

Wheeler, C., Ibeh, K., \& Dimitratos, P. (2008). UK export performance research: Review and implications. International Small Business Journal, 26(2), 207-239.

Wickramasekera, R., \& Oczkowski, E. (2006). Stage models re-visited: A measure of the stage of internationalisation of a firm. Management International Review, 46(1), 39-55.

Yu, Y., \& Lindsay, V. (2016). Export commitment and the global financial crisis: Perspectives from the New Zealand wine industry. Journal of Small Business Management, 54(2), 771-797. 